\title{
Synthesizing greenhouse gas fluxes across nine European peatlands and shrublands - responses to climatic and environmental changes
}

\author{
M. S. Carter ${ }^{1}$, K. S. Larsen ${ }^{1}$, B. Emmett ${ }^{2}$, M. Estiarte ${ }^{3,4}$, C. Field ${ }^{5}$, I. D. Leith ${ }^{6}$, M. Lund ${ }^{7,8}$, A. Meijide , \\ R. T. E. Mills ${ }^{2, *}$, Ü. Niinemets ${ }^{10}$, J. Peñuelas ${ }^{3,4}$, M. Portillo-Estrada ${ }^{10}$, I. K. Schmidt ${ }^{11}$, M. B. Selsted ${ }^{1}$, L. J. Sheppard ${ }^{6}$, \\ A. Sowerby ${ }^{2}$, A. Tietema ${ }^{12}$, and C. Beier ${ }^{1}$ \\ ${ }^{1}$ Centre for Ecosystems and Environmental Sustainability, Department of Chemical and Biochemical Engineering, Technical \\ University of Denmark, 2800 Kgs. Lyngby, Denmark \\ ${ }^{2}$ Centre for Ecology \& Hydrology, Environment Centre Wales, Deiniol Rd, Bangor, Gwynedd, LL57 2UW, UK \\ ${ }^{3}$ CREAF, Cerdanyola del Vallés 08193, Catalonia, Spain \\ ${ }^{4}$ CSIC, Global Ecology Unit CREAF-CEAB-UAB, Cerdanyola del Vallés 08913, Catalonia, Spain \\ ${ }^{5}$ School of Science and the Environment, Manchester Metropolitan University, Chester Street, Manchester, M1 5GD, UK \\ ${ }^{6}$ Centre for Ecology \& Hydrology, Edinburgh, Bush Estate, Penicuik, Midlothian, EH26 0QB, UK \\ ${ }^{7}$ Department of Earth and Ecosystem Sciences, Lund University, Sölvegatan 12, 22362 Lund, Sweden \\ ${ }^{8}$ Department of Bioscience, Aarhus University, Frederiksborgvej 399, P.O. Box 358, 4000 Roskilde, Denmark \\ ${ }^{9}$ European Commission - DG Joint Research Centre, Institute for Environment and Sustainability, Climate Change and Air \\ Quality Unit, Via Enrico Fermi 2749 I21027 Ispra (VA), Italy \\ ${ }^{10}$ Institute of Agricultural and Environmental Sciences, Estonian University of Life Sciences, Kreutzwaldi 1, Tartu 51014, \\ Estonia \\ ${ }^{11}$ Department of Geoscience, Natural Resources and Planning, University of Copenhagen, Rolighedsvej 23, 1958 \\ Frederiksberg, Denmark \\ ${ }^{12}$ Institute for Biodiversity and Ecosystem Dynamics, University of Amsterdam, P.O. Box 94240, 1090 GE Amsterdam, \\ The Netherlands \\ *now at: Ecole Polytechnique Fédérale de Lausanne (EPFL), Laboratory of Ecological Systems, Station 2, 1015 Lausanne, \\ Switzerland
}

Correspondence to: M. S. Carter (mthy@kt.dtu.dk)

Received: 22 December 2011 - Published in Biogeosciences Discuss.: 23 March 2012

Revised: 29 August 2012 - Accepted: 6 September 2012 - Published: 4 October 2012

\begin{abstract}
In this study, we compare annual fluxes of methane $\left(\mathrm{CH}_{4}\right)$, nitrous oxide $\left(\mathrm{N}_{2} \mathrm{O}\right)$ and soil respiratory carbon dioxide $\left(\mathrm{CO}_{2}\right)$ measured at nine European peatlands $(n=4)$ and shrublands $(n=5)$. The sites range from northern Sweden to Spain, covering a span in mean annual air temperature from 0 to $16^{\circ} \mathrm{C}$, and in annual precipitation from 300 to $1300 \mathrm{~mm} \mathrm{yr}^{-1}$. The effects of climate change, including temperature increase and prolonged drought, were tested at five shrubland sites. At one peatland site, the long-term ( $>30 \mathrm{yr}$ ) effect of drainage was assessed, while increased nitrogen deposition was investigated at three peatland sites.

The shrublands were generally sinks for atmospheric $\mathrm{CH}_{4}$, whereas the peatlands were $\mathrm{CH}_{4}$ sources, with fluxes ranging
\end{abstract}

from -519 to $+6890 \mathrm{mg} \mathrm{CH}_{4}-\mathrm{C} \mathrm{m}^{-2} \mathrm{yr}^{-1}$ across the studied ecosystems. At the peatland sites, annual $\mathrm{CH}_{4}$ emission increased with mean annual air temperature, while a negative relationship was found between net $\mathrm{CH}_{4}$ uptake and the soil carbon stock at the shrubland sites. Annual $\mathrm{N}_{2} \mathrm{O}$ fluxes were generally small ranging from -14 to $42 \mathrm{mg} \mathrm{N}_{2} \mathrm{O}-\mathrm{N} \mathrm{m}^{-2} \mathrm{yr}^{-1}$. Highest $\mathrm{N}_{2} \mathrm{O}$ emission occurred at the sites that had highest nitrate $\left(\mathrm{NO}_{3}^{-}\right)$concentration in the soil water. Furthermore, experimentally increased $\mathrm{NO}_{3}^{-}$deposition led to increased $\mathrm{N}_{2} \mathrm{O}$ efflux, whereas prolonged drought and long-term drainage reduced the $\mathrm{N}_{2} \mathrm{O}$ efflux. Soil $\mathrm{CO}_{2}$ emissions in control plots ranged from 310 to $732 \mathrm{~g} \mathrm{CO}_{2}-\mathrm{C} \mathrm{m}^{-2} \mathrm{yr}^{-1}$. Drought and long-term drainage 
generally reduced the soil $\mathrm{CO}_{2}$ efflux, except at a hydric shrubland where drought tended to increase soil respiration.

In terms of fractional importance of each greenhouse gas to the total numerical global warming response, the change in $\mathrm{CO}_{2}$ efflux dominated the response in all treatments (ranging $71-96 \%$ ), except for $\mathrm{NO}_{3}^{-}$addition where $89 \%$ was due to change in $\mathrm{CH}_{4}$ emissions. Thus, in European peatlands and shrublands the effect on global warming induced by the investigated anthropogenic disturbances will be dominated by variations in soil $\mathrm{CO}_{2}$ fluxes.

\section{Introduction}

Shrublands are natural or semi-natural nutrient poor ecosystems, characterized by patches of low stature vascular vegetation alternating with bryophytes or bare soil. Commonly, the shrublands on poorly drained, deep organic soils $(>30 \mathrm{~cm})$ are called peatlands (Lai, 2009) while shrublands on mineral soils, which are typically excessively drained, are called shrublands sensu stricto (Beier et al., 2009). These ecosystem types make up approximately $7 \%$ of the European land area (EEA, 2006; Montanarella et al., 2006) and may contribute valued ecosystem services, such as biodiversity, habitat provision, recreation, water purification and carbon (C) sequestration (Wessel et al., 2004; Kimmel and Mander, 2010). For instance, northern peatlands were estimated to sequester

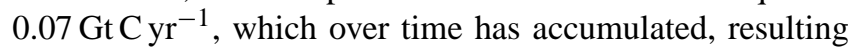
in deep organic soil profiles that constitute a major store of terrestrial C (Gorham, 1991; Clymo et al., 1998). Peatlands and shrublands are sensitive to disturbances such as climate change and management, and the responses to these anthropogenic disturbances are therefore important for the overall European greenhouse gas (GHG) budget and other ecosystem services.

In Europe, peatlands are most abundant under the subarctic and temperate climates of the Nordic countries, where Finland and Sweden together account for $65 \%$ of the European area of peat soils (Montanarella et al., 2006). The geographical distribution of shrublands in Europe includes the heather-moorlands on the British Isles, dry Calluna heaths along the Atlantic coastlines from northern Norway to northern Portugal, and finally maquis ecosystems under the Mediterranean climate in southern Europe (Beier et al., 2009).

Peatlands and shrublands share some common properties concerning vegetation and nutrient status, but they also differ fundamentally, especially in terms of hydrology, with related differences in soil structure, thermal properties and redox state. Such differences may lead to deviation in their respective drivers of GHG fluxes. Methane $\left(\mathrm{CH}_{4}\right)$ fluxes between soil and atmosphere represent the balance between $\mathrm{CH}_{4}$ production and $\mathrm{CH}_{4}$ oxidation. Peatlands are generally net $\mathrm{CH}_{4}$ sources, where $\mathrm{CH}_{4}$ efflux is controlled by water table depth, temperature and availability and quality of carbon substrates (Christensen et al., 2003; Lai, 2009). Presence and composition of vascular vegetation can also affect the $\mathrm{CH}_{4}$ flux dynamics, both through root exudation of labile $\mathrm{C}$ substrates for $\mathrm{CH}_{4}$ production (Ström et al., 2003), and by providing gas conduits, which may influence $\mathrm{CH}_{4}$ production, oxidation and transport processes (Joabsson et al., 1999). In contrast, dry Calluna heaths and Mediterranean shrublands are usually $\mathrm{CH}_{4}$ sinks, where $\mathrm{CH}_{4}$ uptake most often correlates positively with temperature and negatively with soil water content (Castaldi and Fierro, 2005; Carter et al., 2011). The latter is due to the slower gas diffusion in water than in air, which causes soil water to limit $\mathrm{CH}_{4}$ diffusion towards the zone of methanotrophic activity (Dunfield, 2007), mainly located in the upper $20 \mathrm{~cm}$ soil layer (e.g. Roslev et al., 1997).

Peatlands and shrublands also differ in the key drivers of nitrous oxide $\left(\mathrm{N}_{2} \mathrm{O}\right)$ fluxes, which may involve at least two microbial processes, nitrification and denitrification, occurring under aerobic and anaerobic soil conditions, respectively (Baggs, 2011). Generally, the rates of these processes increase with nitrogen $(\mathrm{N})$ availability. In a shallow peatland in Scotland, a spatial analysis revealed a negative correlation between $\mathrm{N}_{2} \mathrm{O}$ emissions and soil $\mathrm{pH}$, possibly an indirect result of limited soil $\mathrm{N}$ availability for the microbes at locations with higher $\mathrm{pH}$ values (Dinsmore et al., 2009), where the vegetation constitutes a stronger $\mathrm{N}$ sink. The temporal $\mathrm{N}_{2} \mathrm{O}$ dynamics were primarily controlled by soil temperature with an apparent switch from consumption to production at about $8^{\circ} \mathrm{C}$ (Dinsmore et al., 2009). Fluxes of $\mathrm{N}_{2} \mathrm{O}$ in shrublands have only been investigated in a few studies, and knowledge of key drivers specific for this ecosystem type is sparse (e.g. Curtis et al., 2006; Carter et al., 2011). In four British moorlands, Curtis et al. (2006) detected either very low or no $\mathrm{N}_{2} \mathrm{O}$ emission. Incubation of soil cores, however, demonstrated that $\mathrm{N}_{2} \mathrm{O}$ efflux could be induced by warming and $\mathrm{N}$ addition. In a Danish Calluna heath, both soil moisture and temperature stimulated $\mathrm{N}_{2} \mathrm{O}$ emissions (Carter et al., 2011).

Soil respiratory $\mathrm{CO}_{2}$ emission originates from decomposition of soil organic matter and from plant root respiration. Together with gross ecosystem photosynthesis, soil respiratory $\mathrm{CO}_{2}$ emission is the dominant flux of carbon between terrestrial ecosystems and the atmosphere (Schlesinger and Andrews, 2000), and changes in soil respiration in response to climate treatments is an important indicator for ecosystems' feedback to climate change. Soil $\mathrm{CO}_{2}$ effluxes from peatlands typically correlate positively with both temperature and water table depth (Smith et al., 2003; Danevčič et al., 2010). Similarly for shrublands, soil $\mathrm{CO}_{2}$ emissions were shown to be strongly controlled by temperature in an analysis based on two years of data from four European heathlands (Emmett et al., 2004).

The relative contribution to global warming of the three greenhouse gases $\mathrm{CH}_{4}, \mathrm{~N}_{2} \mathrm{O}$ and soil respiratory $\mathrm{CO}_{2}$ may vary between peatlands and shrublands. For instance, annual 
GHG budgets for a minerotrophic fen in Finland and a shallow peatland in Scotland showed that $\mathrm{N}_{2} \mathrm{O}$ fluxes were generally of minor importance, whereas $\mathrm{CH}_{4}$ emissions and net ecosystem $\mathrm{CO}_{2}$ exchange exerted the greatest impact on the ecosystem's contribution to global warming (Drewer et al., 2010). For comparison, in an old Kunzea ericoides shrubland in New Zealand, GHG emissions were dominated by $\mathrm{CO}_{2}$ release from the soil while pronounced $\mathrm{CH}_{4}$ uptake more than counteracted $\mathrm{N}_{2} \mathrm{O}$ emissions on a $\mathrm{CO}_{2}$-equivalent basis (Price et al., 2010). Similar studies for European shrublands are currently lacking.

In future, the exchange of GHGs between ecosystems and the atmosphere may be affected by climate change, including increasing temperatures and increased duration and frequency of summer droughts; the latter expected in western and southern Europe (IPCC, 2007a). For instance, Emmett et al. (2004) reported 0-19\% increases in soil $\mathrm{CO}_{2}$ effluxes in response to $0.5-2{ }^{\circ} \mathrm{C}$ warming across four of the five shrublands described in this study. Furthermore, Carter et al. (2011) found a $20 \%$ increase in $\mathrm{CH}_{4}$ uptake rates under elevated temperature in a dry temperate heathland (DKBra in this study). Emissions of $\mathrm{N}_{2} \mathrm{O}$ from this site were reduced and stimulated by drought and elevated temperature, respectively, but only when these treatments were combined with elevated atmospheric $\mathrm{CO}_{2}$ concentrations (Carter et al., 2011).

In addition to climate change, the hydrology of peatlands is affected by other anthropogenic disturbances, such as extensive drainage operations to enable forestry, agriculture or peat harvesting. Drainage of peatland was particularly widespread in the northern temperate zone before the 1980s (Kimmel and Mander, 2010), leading to elevated $\mathrm{CO}_{2}$ effluxes (von Arnold et al., 2005) and to decreased $\mathrm{CH}_{4}$ emissions (Roulet and Moore, 1995), although emissions of $\mathrm{CH}_{4}$ can be significant from drainage ditches in nutrient-rich fens (Minkkinen and Laine, 2006). By contrast, $\mathrm{N}_{2} \mathrm{O}$ emissions from ombrotrophic bogs are relatively insensitive to changes in the water table, as the efflux is probably limited mainly by slow $\mathrm{N}$ transformation rates caused by low $\mathrm{pH}$ and nutrient availability (Martikainen et al., 1993).

A less well understood anthropogenic influence on GHG fluxes in peatlands and shrublands is the effect of enhanced atmospheric $\mathrm{N}$ deposition, originating from intensive agriculture (reduced $\mathrm{N}$ ) and fossil fuel combustion (oxidized $\mathrm{N})$. The global $\mathrm{N}$ pollution is unlikely to decline in the immediate future (Galloway et al., 2004; Peñuelas et al., 2012). Bragazza et al. (2006) investigated peatlands along an atmospheric $\mathrm{N}$ deposition gradient ranging from 2 to $20 \mathrm{~kg} \mathrm{~N} \mathrm{ha}^{-1} \mathrm{yr}^{-1}$ and found increased soil respiratory $\mathrm{CO}_{2}$ emissions under higher $\mathrm{N}$ deposition rates. This relationship was explained by the removal of $\mathrm{N}$ constraints on microbial metabolism and by improved litter quality. The effects of increased $\mathrm{N}$ availability on $\mathrm{CH}_{4}$ exchange are dependent on site specific properties. Some soils show inhibitory effects on $\mathrm{CH}_{4}$ oxidation (Crill et al., 1994; Christensen et al., 1999), while others show minor or no effects (Saarnio and Silvola, 1999). If the abundance of vascular plants increases in peatlands as a result of higher $\mathrm{N}$ availability, this may increase $\mathrm{CH}_{4}$ emissions by providing gas conduits and improving litter quality (Joabsson et al., 1999; Nykänen et al., 2002). Increasing the amount of inorganic $\mathrm{N}$ in a soil will also enhance the potential for $\mathrm{N}_{2} \mathrm{O}$ emissions both through nitrification and denitrification processes (Firestone and Davidson, 1989).

Experimental manipulation studies at the field scale, as well as studies along natural gradients, are valuable tools to understand how ecosystems will respond to climatic and environmental changes. While manipulation studies are wellsuited to study effects of changes in specific experimentally controlled drivers, they are intrinsically constrained in time (years). Natural gradient studies are better suited to study effects on longer time scales (decades to centuries), but suffer from possible biases caused by changes in factors other than the gradient component under investigation, for example, climate. Studies based on a combination of experimental manipulations performed across multiple sites covering larger natural gradients should combine the strengths of both strategies and increase the reliability of the results.

Within the framework of the NitroEurope Integrated Project, we investigated how the soil-atmosphere exchange of the three greenhouse gases, $\mathrm{CH}_{4}, \mathrm{~N}_{2} \mathrm{O}$ and $\mathrm{CO}_{2}$, responded to simulated changes in drought, warming, drainage or nitrogen addition at nine experimental peatland and shrubland sites situated across natural gradients in precipitation and temperature. The aims of the study were (i) to identify environmental variables that correlated with GHG fluxes across the nine sites or within an ecosystem type, (ii) to evaluate whether specific variables had a direct effect on GHG fluxes and thereby could be identified as key drivers based on treatment responses at the site level, and (iii) to quantify the relative contribution of each GHG to the total global warming response for each experimental treatment.

\section{Materials and methods}

\subsection{Study sites}

The nine experimental peatland and shrubland sites included in the synthesis were all part of the NitroEurope project. The climatic conditions at the field sites ranged from subarctic conditions in northern Sweden to a Mediterranean climate in Spain, and from hydric temperate conditions in Wales to mesic temperate climates towards Estonia in the east (Fig. 1). The ecosystems represented open landscapes in these regions and included four peatlands and five shrublands (Table 1). The peatlands were all ombrotrophic bogs, while the shrublands covered heather-moorland (UK-Clo), dry Calluna heath (DK-Mol, DK-Bra, NL-Old) and Mediterranean garrigue shrubland (ES-Gar). Soil type and plant species 
Table 1. Site characteristics.

\begin{tabular}{|c|c|c|c|c|c|c|}
\hline $\begin{array}{l}\text { Ecosystem and } \\
\text { location }\end{array}$ & Coordinates & $\begin{array}{r}\text { Altitude } \\
(\mathrm{m})\end{array}$ & $\begin{array}{l}\text { Site } \\
\text { code }\end{array}$ & Soil type & Dominant vegetation $^{a}$ & Experimental treatment \\
\hline \multicolumn{7}{|l|}{ Peatland } \\
\hline Männikjärve, EE & $58^{\circ} 52^{\prime} \mathrm{N} 26^{\circ} 14^{\prime} \mathrm{E}$ & 80 & EE-Män & Histosol & $\begin{array}{l}\text { S. fuscum, S. rubellum, Scheuchzeria } \\
\text { palustris, Ledum palustre, Vaccinium } \\
\text { oxycoccus, Chamaedaphne calyculata, } \\
\text { Betula pubescencs, Pinus sylvestris }\end{array}$ & Drainage \\
\hline Storflaket, SE & $68^{\circ} 20^{\prime} \mathrm{N} 18^{\circ} 58^{\prime} \mathrm{E}$ & 380 & SE-Sto & Histosol & $\begin{array}{l}\text { S. fuscum, S. balticum, E. nigrum, } \\
\text { Andromeda polifolia, Rubus } \\
\text { chamaemorus, E. vaginatum }\end{array}$ & $\mathrm{N}$ addition $\left(\mathrm{NH}_{4} \mathrm{NO}_{3}\right)$ \\
\hline Fäjemyr, SE & $56^{\circ} 15^{\prime} \mathrm{N} 13^{\circ} 33^{\prime} \mathrm{E}$ & 140 & SE-Fäj & Histosol & $\begin{array}{l}\text { C. vulgaris, Erica tetralix, } \\
\text { S. magellanicum, S. rubellum, } \\
\text { E. vaginatum }\end{array}$ & $\mathrm{N}$ addition $\left(\mathrm{NH}_{4} \mathrm{NO}_{3}\right)$ \\
\hline Whim, UK & $55^{\circ} 45^{\prime} \mathrm{N} 03^{\circ} 16^{\prime} \mathrm{E}$ & 280 & UK-Whi & Histosol & $\begin{array}{l}\text { C. vulgaris, E. vaginatum, } \\
\text { S. capillifolium }\end{array}$ & $\mathrm{N}$ addition $\left(\mathrm{NH}_{4}\right.$ or $\left.\mathrm{NO}_{3}\right)$ \\
\hline \multicolumn{7}{|l|}{ Shrubland } \\
\hline Clocaenog, UK & 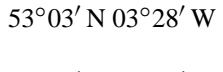 & 490 & UK-Clo & Peaty podzol & $\begin{array}{l}\text { C. vulgaris, Vaccinium myrtillus, } \\
\text { E. nigrum }\end{array}$ & Drought, warming \\
\hline Mols, DK & $56^{\circ} 23^{\prime} \mathrm{N} 10^{\circ} 29^{\prime} \mathrm{E}$ & 57 & DK-Mol & Sandy podzol & C. vulgaris, Deschampsia flexuosa & Drought, warming \\
\hline Brandbjerg, DK & $55^{\circ} 53^{\prime} \mathrm{N} 11^{\circ} 58^{\prime} \mathrm{E}$ & 9 & DK-Bra & Sandy podzol & C. vulgaris, Deschampsia flexuosa & Drought, warming \\
\hline Oldebroek, NL & $52^{\circ} 24^{\prime} \mathrm{N} 05^{\circ} 54^{\prime} \mathrm{E}$ & 25 & NL-Old & Sandy podzol & C. vulgaris & Drought, warming \\
\hline Garraf, ES & $41^{\circ} 19^{\prime} \mathrm{N} 01^{\circ} 49^{\prime} \mathrm{E}$ & 210 & ES-Gar & Petrocalcic calcisol & Erica multiflora, Globularia alypum & Drought, warming \\
\hline
\end{tabular}

${ }^{a}$ C. vulgaris - Calluna vulgaris, E. nigrum - Empetrum nigrum, E. vaginatum - Eriophorum vaginatum, S. - Sphagnum.

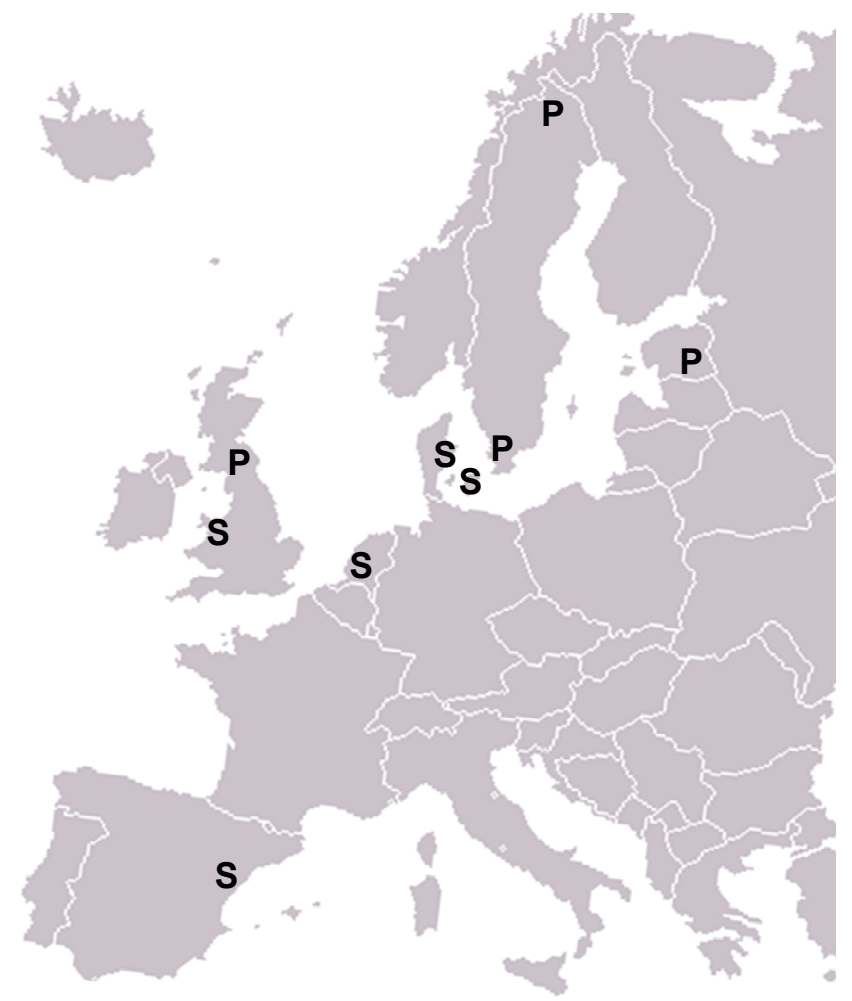

Fig. 1. Location of the nine experimental sites across Europe. Abbreviations are P for "peatland" and S for "shrubland". composition differed between the sites, but all sites had dwarf shrubs in common, mainly Calluna vulgaris, Empetrum nigrum or Erica spp. (Table 1). The experimental sites existed before the NitroEurope project started and therefore already had ongoing methodologies and procedures.

\subsection{Experimental manipulations}

At the Estonian peatland EE-Män, the long-term effect of drainage was studied in a part of the bog where a drainage ditch system established in the 1950s (Veber, 1974) was reconstructed in 1975 (Table 1). Substantial lowering of the water table has resulted in significantly improved tree growth (Niinemets et al., 2001; Portsmuth et al., 2005). Thus, when this study took place, Pinus sylvestris was 10-12 $\mathrm{m}$ tall in the drained part of the bog compared to 1-3 $\mathrm{m}$ in the non-drained part. The effect of increased nitrogen deposition was investigated at three peatland sites. At the two Swedish sites SE-Sto and SE-Fäj, fertilized plots received $\mathrm{NH}_{4} \mathrm{NO}_{3}$ three times per year, corresponding to a total input of $4 \mathrm{~g} \mathrm{~N} \mathrm{~m}^{-2} \mathrm{yr}^{-1}$ (Lund et al., 2009). At the Scottish peatland UK-Whi, treatment plots were given an extra $5.6 \mathrm{~g} \mathrm{~N} \mathrm{~m}^{-2} \mathrm{yr}^{-1}$ in wet deposition using an automated sprinkler system, which provided ca. 120 artificial rain events per year coupled to rainfall (Sheppard et al., 2011). Nitrogen was applied either in the reduced form as $\mathrm{NH}_{4} \mathrm{Cl}$ or in the oxidized form as $\mathrm{NaNO}_{3}$. The effects of temperature increase and prolonged drought were tested at the five shrubland sites using passive night-time warming and horizontal rainout curtains, respectively. The experimental 
setups at these sites are described in more detail by Beier et al. (2004) and Mikkelsen et al. (2008).

\subsection{Soil greenhouse gas flux measurements}

Fluxes of $\mathrm{CH}_{4}, \mathrm{~N}_{2} \mathrm{O}$ and soil respiratory $\mathrm{CO}_{2}$ were measured monthly or twice a month using static chamber methods described by, for example, Carter et al. (2011) and Sowerby et al. (2008). The chamber design and the measurement procedure varied across the nine sites. Overall, at least five weeks before simultaneous measurement of $\mathrm{CH}_{4}$ and $\mathrm{N}_{2} \mathrm{O}$ fluxes started, a permanent soil collar was installed in each replicated treatment plot $(n \geq 3)$ on which a chamber was placed during measurements. Three to four times during the enclosure period of 20-180 min, a sample of headspace air was collected using a syringe through a septum in the chamber. At the Spanish shrubland ES-Gar, however, only two gas samples were collected during the 15 min enclosure period to avoid adverse effects on headspace air pressure in the small chambers (volume 0.81) used at this site. Gas samples were stored in plastic syringes (SE-Sto), pre-evacuated vials (UK-Clo, NL-Old) or non-evacuated vials using a doubleneedle approach (EE-Män, UK-Whi, DK-Mol, DK-Bra, ESGar) before analysis for $\mathrm{CH}_{4}$ and $\mathrm{N}_{2} \mathrm{O}$ concentrations by gas chromatography. One exception was the Swedish site SE-Fäj, where headspace concentrations of $\mathrm{CH}_{4}$ and $\mathrm{N}_{2} \mathrm{O}$ were determined in the field using a photoacoustic gas analyzer (Lund et al., 2009). Previous studies showed that gas flux rates measured using a photoacoustic gas analyzer were statistically identical to flux rates based gas sampling and analysis by gas chromatography (Ambus and Robertson, 1998; Lund et al., 2009). Soil $\mathrm{CO}_{2}$ emissions were measured within permanent collars without vegetation, i.e. where any aboveground plant growth was removed on a regular basis. However, at the two Swedish sites SE-Sto and SE-Fäj, fluxes were assessed on vegetated plots and are therefore ecosystem respiratory $\mathrm{CO}_{2}$ emissions. Generally, an opaque chamber was placed on the collar and the build-up of $\mathrm{CO}_{2}$ during the enclosure period was monitored by a portable infrared gas analyzer. At three out of nine sites (EE-Män, NL-Old and ES-Gar), vascular plant free patches enabled soil $\mathrm{CO}_{2}$ emissions to be determined concurrently with $\mathrm{CH}_{4}$ and $\mathrm{N}_{2} \mathrm{O}$ fluxes using the same chamber and gas chromatography approach. For all three gases, the flux rates were calculated using linear regression of headspace concentration versus time, except for long enclosure periods ( $\geq 120 \mathrm{~min}$ ), where $\mathrm{CH}_{4}$ uptake was determined by fitting a first-order function.

The year of measurement deviated between sites, but was generally within the period 2006-2009. Annual cumulative fluxes were obtained by linear interpolation between measurement days. This is a common, but crude, upscaling procedure since measurements carried out at one point in time, and over a relatively short time span, will represent the whole period between two neighboring measurements, despite potentially large variation in the controlling climatic factors during this period. A more precise method would be to model the fluxes based on more frequent measurements of key drivers such as temperature and soil moisture (e.g. Selsted et al., 2012). In the present study, we did not have sufficient measurements to build such a model for each site. At the Swedish peatlands SE-Fäj and SE-Sto, gas flux measurements were not conducted during the five and eight coldest months of the year, respectively. When calculating the annual $\mathrm{CO}_{2}$ fluxes for these two sites, we assumed that the contribution of the winter period to annual fluxes is $9 \%$ at SE-Fäj (Lindroth et al., 2007) and 22\% at SE-Sto (Larsen et al., 2007). These ratios were also used to estimate annual $\mathrm{CH}_{4}$ and $\mathrm{N}_{2} \mathrm{O}$ fluxes, assuming that $\mathrm{CO}_{2}$ fluxes represented the general level of microbial activity; more specifically, that $\mathrm{Q}_{10}$ values for $\mathrm{CO}_{2}, \mathrm{CH}_{4}$ and $\mathrm{N}_{2} \mathrm{O}$ fluxes were not substantially different. Reported $Q_{10}$ values for $\mathrm{CH}_{4}$ and $\mathrm{N}_{2} \mathrm{O}$ fluxes in natural ecosystems are sparse, however, Smith (1997) compiled $Q_{10}$ values for $\mathrm{N}_{2} \mathrm{O}$ emissions ranging 2.8-3.1 and 1.55 in unfertilized grassland and short grass prairie, respectively. This is within the range of $Q_{10}$ values often reported in literature for soil respiratory $\mathrm{CO}_{2}$ emissions (e.g. Kim and Verma, 1992).

\subsection{Precipitation, temperature and soil moisture}

The meteorological measurements included precipitation and air temperature. Soil temperature probes were installed at either $5 \mathrm{~cm}$ depth (EE-Män, SE-Fäj, DK-Bra, ES-Gar) or $10 \mathrm{~cm}$ depth (UK-Whi, UK-Clo, DK-Mol, NL-Old) and data were logged at least twice a day. Volumetric soil water content was measured at least twice a week by time domain reflectometry probes installed in the top $6 \mathrm{~cm}$ (DK-Mol), $10 \mathrm{~cm}$ (SE-Sto, SE-Fäj, UK-Clo, NL-Old), $15 \mathrm{~cm}$ (ES-Gar) or $20 \mathrm{~cm}$ soil layer (DK-Bra). For UK-Whi and EE-Män, volumetric soil moisture in $0-10 \mathrm{~cm}$ depth was calculated from monthly or seasonal measurements of gravimetric soil water content. At the peatland sites, water table depth was measured manually in dipwells or automatically using a pressure transducer.

\subsection{Nitrogen deposition and leaching}

Bulk $\mathrm{N}$ deposition was measured with bulk deposition collectors with a minimum diameter of $10 \mathrm{~cm}$. Concentrations of $\mathrm{NH}_{4}^{+}, \mathrm{NO}_{3}^{-}$and total $\mathrm{N}$ in the sampled precipitation were determined by ion chromatography or colorimetric assays. If bulk $\mathrm{N}$ deposition was not assessed at the site, then total $\mathrm{N}$ deposition reported in the literature for this specific area was used instead. Nitrate leaching was determined from modelled water percolation combined with $\mathrm{NO}_{3}^{-}$concentrations measured in soil water collected below the rooting zone using porous suction cups (Schmidt et al., 2004; Larsen et al., 2011). Soil water was also sampled in the upper part of the soil profile, generally just below the O-horizon, and analyzed for $\mathrm{NH}_{4}^{+}$and $\mathrm{NO}_{3}^{-}$concentrations (e.g. Schmidt et al., 2004). 


\subsection{Plant and soil analyses}

Aboveground biomass $\mathrm{C}$ and $\mathrm{N}$ at the shrubland sites were determined using plant tissue $\mathrm{C}$ and $\mathrm{N}$ analyses combined with biomass estimation based on pinpoint data (Peñuelas et al., 2004; Beier et al., 2009). Briefly, pinpoint measurements were conducted by lowering a sharpened pin through the vegetation, recording species and height for each plant hit with the pin. Total plant biomass was subsequently estimated using a site specific correlation between pinpoint data and actual biomass obtained by destructive samplings outside the experimental plots (Peñuelas et al., 2004). At the Scottish peatland UK-Whi, biomass $\mathrm{C}$ and $\mathrm{N}$ were obtained by destructive harvest. Soil samples collected in the upper soil layer (i.e. generally the O-horizon) were extracted with distilled water (DK-Bra), $1 \mathrm{M} \mathrm{KCl} \mathrm{(UK-Whi,} \mathrm{UK-Clo,} \mathrm{DK-Mol,}$ NL-Old) or $2 \mathrm{M} \mathrm{KCl} \mathrm{(EE-Män,} \mathrm{ES-Gar)} \mathrm{to} \mathrm{measure} \mathrm{concen-}$ trations of extractable $\mathrm{NH}_{4}^{+}$and $\mathrm{NO}_{3}^{-}$by ion chromatography or colorimetric assays (e.g. Andresen et al., 2009). For upper and lower soil layers, soil $\mathrm{pH}$ was determined in a suspension of soil in distilled water, $0.01 \mathrm{M} \mathrm{CaCl}_{2}$ or $1 \mathrm{M} \mathrm{KCl}$. Furthermore, bulk density, total $\mathrm{C}$ and $\mathrm{N}$ contents, and microbial biomass $\mathrm{C}$ were measured as described by Beier et al. (2009), and C stock in the $0-10 \mathrm{~cm}$ soil layer was calculated.

\subsection{Responsiveness}

Relative responsiveness (RR, \%) of $\mathrm{CH}_{4}, \mathrm{~N}_{2} \mathrm{O}$ and $\mathrm{CO}_{2}$ fluxes to the different treatments was calculated as

$\mathrm{RR}=($ Treat - Cont $) /$ Cont $\times 100$

where Treat is mean treatment flux across sites and Cont is

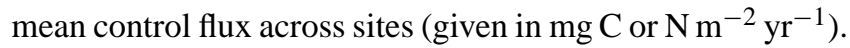
Similar to Liu and Greaver (2009), we refrained from calculating relative responsiveness in cases where the flux changed direction in response to a treatment. This occurred in the $\mathrm{N}$ addition experiments, where $\mathrm{N}_{2} \mathrm{O}$ fluxes changed from net uptake to emission. For each gas species and treatment, we also calculated the absolute responsiveness (AR) in $\mathrm{CO}_{2}-$ equivalents as

$\mathrm{AR}=($ Treat - Cont $) / \mathrm{MR} \times \mathrm{GWP}$

where molar ratio (MR) is $12 / 16,28 / 44$ and $12 / 44$, and global warming potential (GWP) is 25,298 and 1 for $\mathrm{CH}_{4}$, $\mathrm{N}_{2} \mathrm{O}$ and $\mathrm{CO}_{2}$, respectively (IPCC, 2007b). To compare the relative contribution of each gas species to the total global warming response for a specific treatment, we calculated the fractional importance (FI, \%) of each gas species as

$\mathrm{FI}_{i}=\left|\mathrm{AR}_{i}\right| /\left(\left|\mathrm{AR}_{1}\right|+\left|\mathrm{AR}_{2}\right|+\left|\mathrm{AR}_{3}\right|\right) \times 100$

where $\left|\mathrm{AR}_{1}\right|$ to $\left|\mathrm{AR}_{3}\right|$ is the numerical value of the absolute responsiveness for each of the three gases. Numerical values were used in order for the total global warming response of all three gases to sum up to 100 . To clarify, when assessing the overall response patterns across sites and treatments, we calculated RR, AR and FI for all treatments, also including treatments that did not show significant effects on flux rates in the cross-site statistical analysis described below.

\subsection{Statistics}

To assess treatment effects on GHG fluxes across the sites, two-factor analyses of variance (ANOVA) with treatment, site and their interaction as fixed effects were conducted using the PROC MIXED procedure of SAS (SAS Institute, 2003). The random effects included site and treatment $\times$ site. The GHG flux datasets were unbalanced as the number of replicates was unequal between sites, however the MIXED procedure is used in the same way whether data are balanced or unbalanced (Littell et al., 2002). More specifically, equal weight is given to each site regardless of the number of replicates when determining treatment effects. Data were logtransformed as required to obtain normality and homogeneity of variance. Main effects and interactions with $P \leq 0.05$ were considered to be significant, and were interpreted using differences of least squares means.

\section{Results}

\subsection{Precipitation, temperature and soil moisture}

Annual precipitation during the study period ranged from $311 \mathrm{~mm}$ at the subarctic peatland Storflaket in Sweden (SESto) to $1351 \mathrm{~mm}$ at the Welsh shrubland Clocaenog (UKClo) (Table 2). Mean annual air temperature in control plots ranged from $-0.3{ }^{\circ} \mathrm{C}$ at the subarctic site SE-Sto to $15.6^{\circ} \mathrm{C}$ at the Spanish shrubland Garraf (ES-Gar). The passive nighttime warming generally raised annual soil temperature at 5 or $10 \mathrm{~cm}$ depth by $0.5^{\circ} \mathrm{C}$, and decreased the soil water content by $2 \%$ vol. (Table 2). Experimental drought caused a decline in mean annual soil moisture ranging from a reduction of $1.5 \%$ vol. at the Danish shrubland Brandbjerg (DK-Bra) to $10.2 \%$ vol. at the wet shrubland UK-Clo. Drainage of the Estonian peatland Männikjärve (EE-Män) lowered the water table from an annual depth of $15 \mathrm{~cm}$ to $38 \mathrm{~cm}$ below soil surface. Characteristics of the upper and lower soil layers at the sites as well as data on aboveground biomass, $\mathrm{N}$ deposition and leaching are found in the Supplement.

\section{2 $\mathrm{CH}_{4}$ fluxes}

Annual $\mathrm{CH}_{4}$ fluxes in control plots ranged from uptake of $519 \mathrm{mg} \mathrm{C} \mathrm{m}^{-2} \mathrm{yr}^{-1}$ at the Danish shrubland Mols (DK-Mol) to emission of $6890 \mathrm{mg} \mathrm{C} \mathrm{m}^{-2} \mathrm{yr}^{-1}$ from the Scottish peatland Whim (UK-Whi) (Table 3). For the peatland sites, the natural gradient analysis showed a clear relationship between annual $\mathrm{CH}_{4}$ emission and mean annual air temperature (Fig. 2). In contrast, $\mathrm{CH}_{4}$ fluxes at the temperate shrublands 
Table 2. Annual precipitation, air temperature (Air $T$ ), soil temperature (Soil $T$ ) and soil water content (Soil W) during the study period at the nine experimental sites depending on treatment.

\begin{tabular}{llrrrr}
\hline Site & Treatment & $\begin{array}{r}\text { Precipitation } \\
(\mathrm{mm})\end{array}$ & $\begin{array}{r}\text { Air } T \\
\left({ }^{\circ} \mathrm{C}\right)\end{array}$ & $\begin{array}{r}\text { Soil } T \\
\left({ }^{\circ} \mathrm{C}\right)\end{array}$ & $\begin{array}{r}\text { Soil W } \\
(\% \text { vol })\end{array}$ \\
\hline \multirow{2}{*}{ EE-Män } & Control & 889 & 4.3 & 5.6 & 76.7 \\
& Drainage & na & 6.0 & 5.9 & 37.2 \\
SE-Sto & Site data & 311 & -0.3 & na & 23.4 \\
SE-Fäj & Site data & 626 & 7.1 & 7.6 & 59.1 \\
UK-Whi & Site data & 1092 & 8.5 & 7.7 & 71.9 \\
UK-Clo & Control & 1351 & 7.5 & 8.1 & 45.9 \\
& Drought & 1130 & 7.7 & 7.9 & 35.7 \\
& Warming & 1127 & 7.9 & 8.1 & 43.6 \\
DK-Mol & Control & 668 & 8.7 & 9.0 & 17.6 \\
& Drought & 563 & 8.9 & 9.0 & 15.1 \\
& Warming & na & 9.7 & 9.8 & 15.3 \\
DK-Bra & Control & 714 & 10.2 & 8.9 & 16.5 \\
& Drought & na & na & 8.8 & 15.0 \\
& Warming & na & na & 9.4 & 15.0 \\
NL-Old & Control & 986 & 8.3 & 8.8 & 21.8 \\
& Drought & 792 & na & na & 17.1 \\
& Warming & 855 & 9.6 & 9.5 & 16.5 \\
ES-Gar & Control & 550 & 15.6 & 17.0 & 19.8 \\
& Drought & 397 & 15.8 & 16.8 & 17.0 \\
& Warming & 520 & 16.1 & 17.7 & 20.0 \\
\hline
\end{tabular}

na: not assessed.

correlated with the carbon stock in the top $10 \mathrm{~cm}$ soil layer (Fig. 3). Concerning experimental manipulations, the effect of increased $\mathrm{N}$ input was tested at three peatland sites and overall no uniform effect was found on the $\mathrm{CH}_{4}$ efflux $(P=0.65)$ (Table 3). At the peatland UK-Whi, though, additional deposition of oxidized $\mathrm{N}$, corresponding to $5.6 \mathrm{~g} \mathrm{NO}_{3}$ $\mathrm{N} \mathrm{m}^{-2} \mathrm{yr}^{-1}$, resulted in an almost $300 \%$ increase of the annual $\mathrm{CH}_{4}$ emission $(P=0.031)$. Concurrently, soil $\mathrm{pH}$ rose from 3.7 to 4.0 (Table S1). Permanent drainage of the Estonian peatland EE-Män reduced the $\mathrm{CH}_{4}$ efflux substantially $(P=0.003)$, whereas no consistent effect on the $\mathrm{CH}_{4}$ flux was observed for prolonged drought or warming at the shrubland sites $(P \geq 0.49)$ (Fig. 4, Table 3).

\section{3 $\quad \mathrm{N}_{2} \mathrm{O}$ fluxes}

Annual fluxes of $\mathrm{N}_{2} \mathrm{O}$ generally consisted of low efflux rates, although net $\mathrm{N}_{2} \mathrm{O}$ uptake was observed in control plots at the Swedish peatland Fäjemyr (SE-Fäj) and the Scottish peatland UK-Whi (Table 3). Within each of the two ecosystem types, peatland and shrubland, the highest $\mathrm{N}_{2} \mathrm{O}$ efflux occurred at the site with highest soil water $\mathrm{NO}_{3}^{-}$concentration (Fig. 5). The stimulatory effect of $\mathrm{NO}_{3}^{-}$on the $\mathrm{N}_{2} \mathrm{O}$ efflux was supported by the $\mathrm{N}$ deposition experiments. More specifically, the two peatlands SE-Fäj and UK-Whi changed from $\mathrm{N}_{2} \mathrm{O}$ sinks into $\mathrm{N}_{2} \mathrm{O}$ sources as a result of increased $\mathrm{NH}_{4} \mathrm{NO}_{3}$ and $\mathrm{NaNO}_{3}$ input, respectively ( $P=0.011$ ) (Fig. 6a). Overall, differences in volumetric soil water content across sites did not explain the variation in annual $\mathrm{N}_{2} \mathrm{O}$ fluxes for control

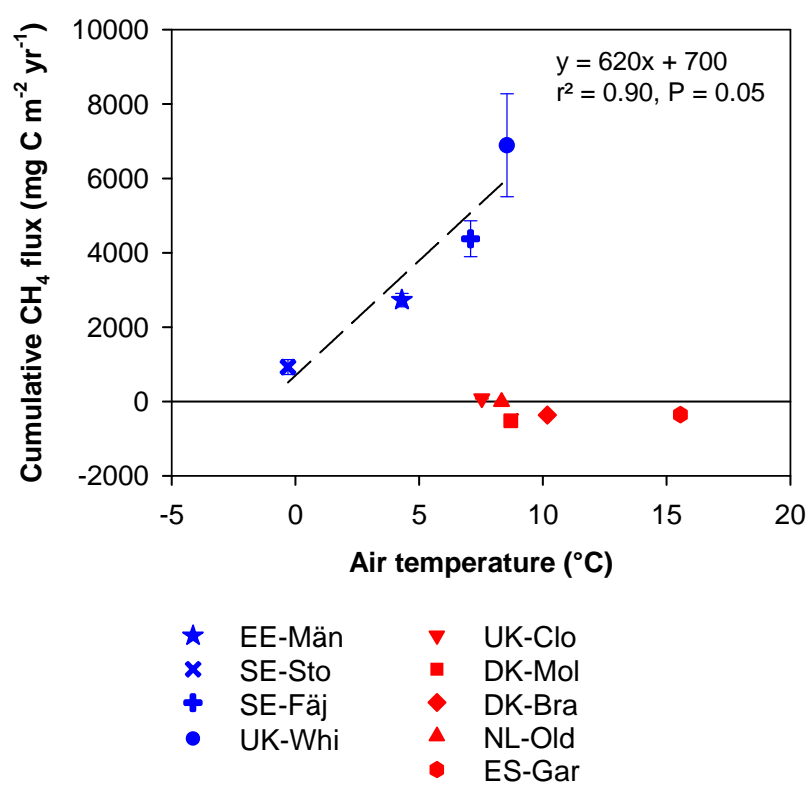

Fig. 2. Annual $\mathrm{CH}_{4}$ flux related to mean annual air temperature in control plots at the nine sites (means $\pm \mathrm{SE}$ ). A linear regression line was fitted to data from the four peatland sites. Site codes are described in Table 1.

Carbon stock at 0-10 $\mathrm{cm}$ depth $\left(\mathrm{kg} \mathrm{C} \mathrm{m}^{-2}\right)$

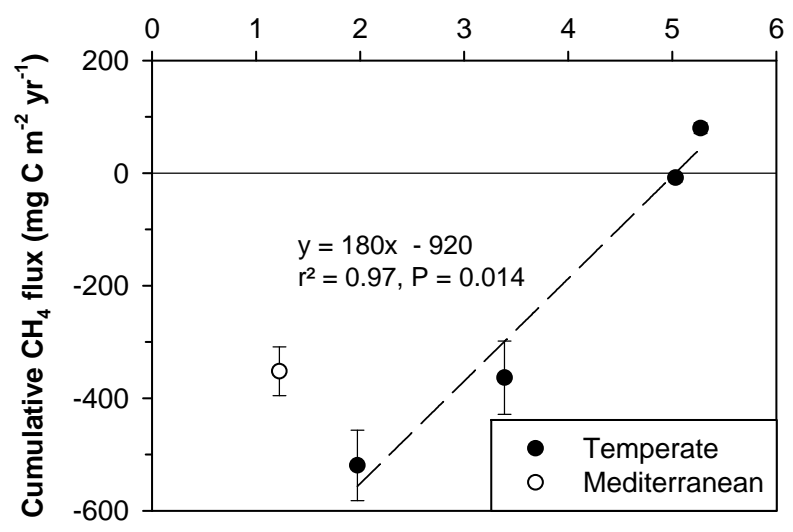

Fig. 3. Annual $\mathrm{CH}_{4}$ flux as a function of carbon stock in the 0 $10 \mathrm{~cm}$ soil layer at five shrubland sites (means $\pm \mathrm{SE}$ ). A linear regression line was fitted to data from the four temperate shrubland sites.

plots (Fig. 6b). At the site level, however, reduced soil moisture caused by drainage or drought consistently reduced the $\mathrm{N}_{2} \mathrm{O}$ efflux $(P=0.0005)$. According to differences of least squares means, this was especially pronounced for drainage at the Estonian peatland EE-Män and for drought at the Dutch shrubland Oldebroek (NL-Old) (site $\times$ treatment; $P=$ $0.034)$. The warming treatment had no effect on $\mathrm{N}_{2} \mathrm{O}$ fluxes $(P=0.47)$ (Table 3). 


\subsection{Soil respiratory $\mathrm{CO}_{2}$ emission}

Soil $\mathrm{CO}_{2}$ emissions ranged between 518 to $732 \mathrm{~g} \mathrm{C} \mathrm{m}^{-2} \mathrm{yr}^{-1}$ at six of the nine sites investigated (Fig. 7a), but was considerable lower at the remaining three sites. As expected, the lowest rate was observed at the northernmost and coldest site SE-Sto $\left(231 \mathrm{~g} \mathrm{C} \mathrm{m}^{-2} \mathrm{yr}^{-1}\right)$, where fluxes were only measured on vegetated plots and therefore are ecosystemlevel respiratory $\mathrm{CO}_{2}$ losses. Consequently, soil respiratory $\mathrm{CO}_{2}$ losses should be even lower than the rate reported here. Soil respiration was also considerably lower at the temperate shrubland NL-Old $\left(310 \mathrm{~g} \mathrm{C} \mathrm{m}^{-2} \mathrm{yr}^{-1}\right)$, and at the southernmost and warmest shrubland ES-Gar $\left(390 \mathrm{~g} \mathrm{C} \mathrm{m}^{-2} \mathrm{yr}^{-1}\right)$, compared to the six sites with highest emissions. Across the five sites where warming was applied as treatment, the temperature rise of $0.5^{\circ} \mathrm{C}$ in the soil had no effect on soil $\mathrm{CO}_{2}$ emissions $(P=0.83)$ (Table 3). At the site level, the $\mathrm{CO}_{2}$ efflux seemed to be more controlled by soil moisture. More specifically, prolonged drought and longterm $(>30 \mathrm{yr})$ drainage overall caused a reduction of soil $\mathrm{CO}_{2}$ emissions $(P=0.003)$ (Fig. 7b). In particular, this was pronounced for drainage at the peatland EE-Män and drought at the dry shrubland DK-Mol, whereas drought tended to have the opposite effect at the wet shrubland UKClo (site $\times$ treatment; $P=0.0086$ ). Increased $\mathrm{N}$ input at three peatland sites had no effect on annual $\mathrm{CO}_{2}$ emissions $(P=0.69)$ (Table 3$)$.

\subsection{Responsiveness of greenhouse gas fluxes}

Relative to control plots, the observed treatment response was generally higher for $\mathrm{CH}_{4}$ and $\mathrm{N}_{2} \mathrm{O}$ fluxes than for $\mathrm{CO}_{2}$ fluxes (Table 4). However, when comparing the fractional importance of each GHG to the total numerical global warming response (GWR), the changes in $\mathrm{CO}_{2}$ emissions dominated the response in all treatments (ranging 71-96\%), except for $\mathrm{NO}_{3}^{-}$additions where $89 \%$ of the total GWR was due to a change in $\mathrm{CH}_{4}$ emissions. Relative to the other GHGs, the impact on GWR from changes in $\mathrm{N}_{2} \mathrm{O}$ fluxes was generally low; only $4 \%$ of total GWR across the shrubland sites and absent across the peatland sites. Across all treatments and gas species, anthropogenic disturbance overall reduced the shrublands' contribution to global warming, while peatlands generally showed an increased contribution for $\mathrm{CH}_{4}$ and a reduced contribution for $\mathrm{CO}_{2}$.

\section{Discussion}

In Europe, open landscapes represented by peatlands and shrublands cover about $7 \%$ of the land area (EEA, 2006; Montanarella et al., 2006). In the current synthesis, we investigated greenhouse gases fluxes between these ecosystems and the atmosphere in order to identify factors that seemed to control cross-site variation in flux rates, either directly or indirectly. Furthermore, we assessed the effect
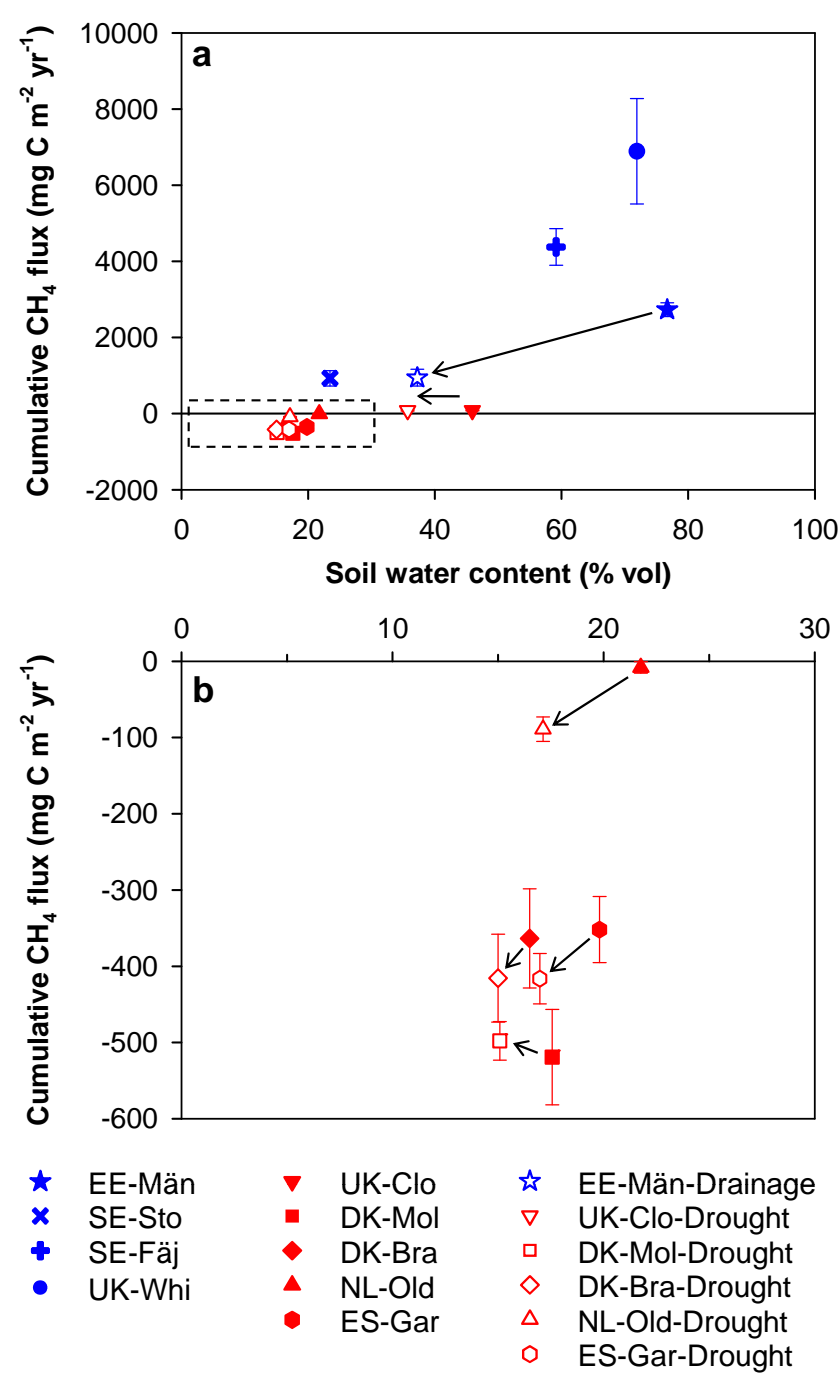

Fig. 4. Annual $\mathrm{CH}_{4}$ flux at the nine sites related to mean annual soil water content, predominantly measured in the top $10 \mathrm{~cm}$ soil layer (means $\pm \mathrm{SE}$ ). Closed symbols are control plots, whereas open symbols are drained or drought treated plots. Arrows indicate direction of treatment responses. In (b), the bottom left corner of (a) has been enlarged. Site codes are described in Table 1.

on the GHG fluxes of anthropogenic disturbances, such as temperature rise and prolonged droughts caused by climate change, drainage of peatlands and increased atmospheric nitrogen deposition.

\section{1 $\mathrm{CH}_{4}$ fluxes}

On a global scale, wetlands are the largest single source of $\mathrm{CH}_{4}$ emission to the atmosphere, accounting for 100 to $231 \mathrm{Tg} \mathrm{CH}_{4} \mathrm{yr}^{-1}$ (IPCC, 2007b), whereas aerobic soils are substantial $\mathrm{CH}_{4}$ sinks, estimated to take up about $22 \mathrm{Tg} \mathrm{CH}_{4} \mathrm{yr}^{-1}$ (Dutaur and Verchot, 2007). The present study illustrates these fundamental differences between 
Table 3. Annual cumulative $\mathrm{CH}_{4}, \mathrm{~N}_{2} \mathrm{O}$ and soil $\mathrm{CO}_{2}$ fluxes at the nine experimental sites depending on treatment (means; $\mathrm{SE}$ in brackets). Number of replicated plots and year of measurement (either one or two years) are also indicated.

\begin{tabular}{|c|c|c|c|c|c|c|c|c|c|c|}
\hline \multirow{2}{*}{$\begin{array}{l}\text { Site } \\
\text { EE-Män }\end{array}$} & \multirow{3}{*}{$\begin{array}{l}\text { Treatment } \\
\text { Control } \\
\text { Drainage }\end{array}$} & \multirow{2}{*}{$\frac{\text { Replicates }}{3}$} & \multicolumn{2}{|c|}{$\begin{array}{c}\mathrm{CH}_{4} \text { flux } \\
\mathrm{mg} \mathrm{C} \mathrm{m}^{-2} \mathrm{yr}^{-1}\end{array}$} & \multicolumn{2}{|c|}{$\begin{array}{c}\mathrm{N}_{2} \mathrm{O} \text { flux } \\
\operatorname{mg~N~m}^{-2} \mathrm{yr}^{-1}\end{array}$} & \multirow{2}{*}{$\begin{array}{c}\text { Year } \\
2008 / 2009\end{array}$} & \multicolumn{2}{|c|}{$\begin{array}{l}\text { Soil CO } \mathrm{CO}_{2} \text { emission } \\
\\
\mathrm{g} \mathrm{C} \mathrm{m}^{-2} \mathrm{yr}^{-1}\end{array}$} & \multirow{2}{*}{$\frac{\text { Year }}{2008 / 200}$} \\
\hline & & & 2729 & $(180)$ & 41.8 & (5.7) & & 528 & (66) & \\
\hline & & & 943 & $(222)$ & 4.1 & (7.9) & & 226 & $(56)$ & \\
\hline \multirow[t]{2}{*}{ SE-Sto } & Control & 4 & 926 & (201) & na & & 2007 & 231 & $(6)$ & 2007 \\
\hline & $\mathrm{NH}_{4} \mathrm{NO}_{3}$ & & 551 & (110) & na & & & 265 & (39) & \\
\hline \multirow[t]{2}{*}{ SE-Fäj } & Control & 4 & 4377 & (482) & -2.4 & (1.8) & 2007 & 522 & (179) & 2007 \\
\hline & $\mathrm{NH}_{4} \mathrm{NO}_{3}$ & & 5883 & (846) & 8.0 & (3.7) & & 585 & $(51)$ & \\
\hline \multirow[t]{3}{*}{ UK-Whi } & Control & 4 & 6890 & (1383) & -14.3 & $(3.5)$ & 2007-2009 & 572 & (69) & $2006 / 2007$ \\
\hline & $\mathrm{NH}_{4}$ & & 7412 & (2590) & 5.5 & (16.6) & & 535 & (51) & \\
\hline & $\mathrm{NO}_{3}$ & & 27020 & (11 101) & 16.1 & (13.2) & & 496 & (26) & \\
\hline \multirow[t]{3}{*}{ UK-Clo } & Control & 3 & 80 & (10) & 10.8 & $(5.7)$ & 2007-2009 & 518 & (32) & $2006 / 2007$ \\
\hline & Drought & & 81 & (12) & 0.8 & (2.7) & & 633 & (12) & \\
\hline & Warming & & 70 & (7) & 11.2 & (2.1) & & 584 & (45) & \\
\hline \multirow[t]{3}{*}{ DK-Mol } & Control & 3 & -519 & (63) & 13.3 & (5.7) & $2006 / 2007$ & 732 & (36) & $2003 / 2004$ \\
\hline & Drought & & -498 & (25) & 9.9 & (4.6) & & 513 & (18) & \\
\hline & Warming & & -552 & (36) & 10.8 & (2.3) & & 730 & (48) & \\
\hline \multirow[t]{3}{*}{ DK-Bra } & Control & 6 & -363 & (65) & 31.0 & (5.6) & $2006 / 2007$ & 651 & (59) & $2006 / 2007$ \\
\hline & Drought & & -416 & (58) & 27.6 & (7.8) & & 600 & (34) & \\
\hline & Warming & & -436 & (78) & 29.5 & $(6.5)$ & & 659 & (52) & \\
\hline \multirow[t]{3}{*}{ NL-Old } & Control & 3 & -8 & (7) & 6.9 & (5) & 1999 & 310 & (48) & 1999 \\
\hline & Drought & & -89 & (16) & -30.4 & (10.2) & & 285 & (72) & \\
\hline & Warming ${ }^{\mathrm{c}}$ & & 29 & (20) & -2.3 & $(2.3)$ & & 330 & (45) & \\
\hline \multirow[t]{3}{*}{ ES-Gar } & Control & 3 & -352 & (43) & na & & $2007 / 2008$ & 390 & (30) & $2007 / 2008$ \\
\hline & Drought & & -416 & (33) & na & & & 298 & (19) & \\
\hline & Warming & & -432 & (42) & na & & & 335 & (21) & \\
\hline
\end{tabular}

${ }^{\text {a }}$ Fluxes of $\mathrm{N}_{2} \mathrm{O}$ were not assessed (na) at SE-Sto and ES-Gar.

b Data for SE-Sto and SE-Fäj is ecosystem respiratory $\mathrm{CO}_{2}$ emission.

c At NL-Old, the warming treatment started in May 1999.

Table 4. Relative responsiveness to treatments compared to controls (\%), absolute responsiveness $\left(\mathrm{CO}_{2}\right.$-equivalents), and fractional importance of each greenhouse gas to the total numerical global warming response (in brackets, \%) for soil $\mathrm{CH}_{4}, \mathrm{~N}_{2} \mathrm{O}$ and $\mathrm{CO}_{2}$ fluxes across all sites.

\begin{tabular}{|c|c|c|c|c|c|c|c|c|c|}
\hline \multirow{3}{*}{$\frac{\text { Treatment }^{\mathrm{a}}}{\text { Drainage }}$} & \multicolumn{3}{|c|}{$\begin{array}{c}\text { Relative } \\
\text { responsiveness (\%) }\end{array}$} & \multicolumn{6}{|c|}{$\begin{array}{c}\text { Absolute } \\
\text { responsiveness }\left(\mathrm{CO}_{2} \text {-eq }\right)\end{array}$} \\
\hline & \multirow{2}{*}{$\frac{\mathrm{CH}_{4}}{-65}$} & \multirow{2}{*}{$\frac{\mathrm{N}_{2} \mathrm{O}^{\mathrm{b}}}{-90}$} & \multirow{2}{*}{$\begin{array}{r}\mathrm{CO}_{2} \\
-57\end{array}$} & \multicolumn{2}{|c|}{$\mathrm{CH}_{4}$} & \multicolumn{2}{|c|}{$\mathrm{N}_{2} \mathrm{O}$} & \multicolumn{2}{|c|}{$\mathrm{CO}_{2}$} \\
\hline & & & & -74 & $(6)$ & -18 & (2) & -1107 & $(92)$ \\
\hline $\mathrm{N}$ addition, including $\mathrm{NH}_{4}$ & 14 & na & 5 & 23 & (22) & 7 & (7) & 73 & (71) \\
\hline $\mathrm{N}$ addition, including $\mathrm{NO}_{3}$ & 174 & na & 2 & 295 & (89) & 10 & (3) & 25 & (8) \\
\hline Drought & -15 & -87 & -11 & -1 & (1) & -6 & (3) & -201 & (96) \\
\hline Warming & -14 & -21 & 1 & -1 & (4) & -1 & (5) & 27 & (91) \\
\hline Peatlands all treatments & 124 & 0.4 & -9 & 193 & (56) & 0 & $(0)$ & -153 & (44) \\
\hline Shrublands all treatments & -14 & -54 & -5 & -1 & (2) & -4 & (4) & -87 & (94) \\
\hline
\end{tabular}

a Responsiveness is reported for the treatments "warming" and " $\mathrm{N}$ addition, including $\mathrm{NH}_{4}$ " although cross-site statistical analyses showed no significant effects on any of the gas species.

$\mathrm{b}$ na: not assessed due to change in flux direction.

ecosystem types depending on water table depth with peatlands as $\mathrm{CH}_{4}$ sources and shrublands generally as $\mathrm{CH}_{4}$ sinks. The $\mathrm{CH}_{4}$ emission from peatlands correlated positively with temperature when analyzed across the four sites. Although our natural gradient analyses could be biased by differences in measurement years and methods, the results are in line with Christensen et al. (2003) who compared $\mathrm{CH}_{4}$ fluxes measured during the growing season at five northern wetlands covering Greenland, Iceland, Scandinavia and Siberia. They estimated that soil temperature explained $84 \%$ of the 


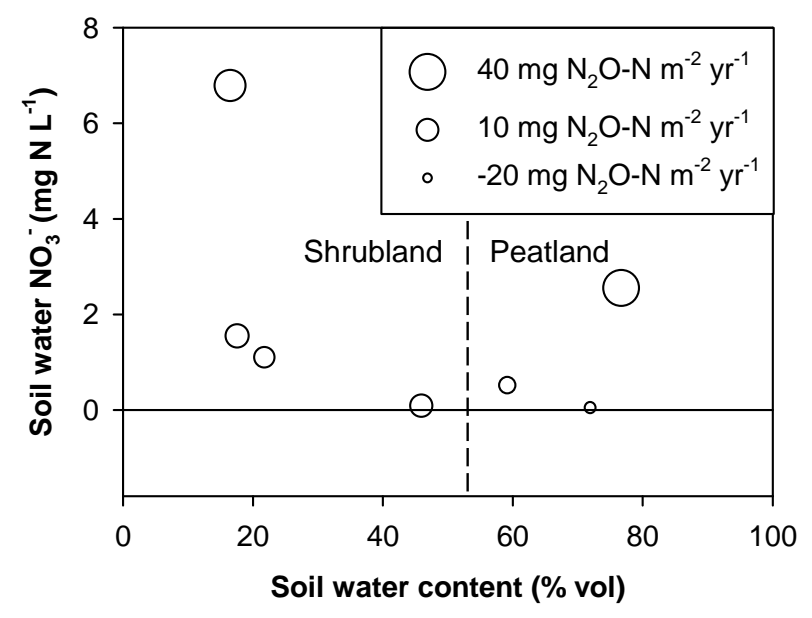

Fig. 5. Size of annual $\mathrm{N}_{2} \mathrm{O}$ flux plotted against mean annual soil water content and nitrate concentration in soil water. Data derive from control plots at seven sites that are divided into shrublands and peatlands by the dashed line.

variability in mean seasonal $\mathrm{CH}_{4}$ emissions, and suggested that availability of organic acids in peat water accounted for the remaining $16 \%$ of the $\mathrm{CH}_{4}$ fluxes variability across the sites. The stimulating effect of increased temperature on net $\mathrm{CH}_{4}$ emissions from peatlands can be explained by basic $\mathrm{CH}_{4}$ biochemistry as processes related to $\mathrm{CH}_{4}$ production are more temperature dependent than those associated with methane oxidation (Dunfield et al., 1993). However, the simple temperature relationship of $\mathrm{CH}_{4}$ emissions may also include other interrelated factors, most importantly plant productivity affecting substrate quality and quantity, but also plant aerenchyma development allowing $\mathrm{CH}_{4}$ produced in the soil to be released into the atmosphere (Joabsson et al., 1999). Based on the current dataset, we are not able to distinguish whether temperature affected the $\mathrm{CH}_{4}$ efflux directly or indirectly, and most likely several of the temperature-related mechanisms above acted simultaneously. Nevertheless, our natural gradient analysis suggests that temperature could be used as a common indicator when estimating the magnitude of $\mathrm{CH}_{4}$ emissions from peatlands across wide regional scales. Furthermore, the analysis reveals that $\mathrm{CH}_{4}$ emissions from peatlands may rise in the future as a result of the predicted temperature increases caused by climate change.

In a global analysis of $\mathrm{CH}_{4}$ uptake by aerobic soils, Dutaur and Verchot (2007) found that soil texture strongly controlled $\mathrm{CH}_{4}$ uptake with coarse textured soils consuming more $\mathrm{CH}_{4}$ than other texture classes. All temperate shrublands in our study had a sandy mineral soil layer, while the soils differed in the properties of the organic layer, which consisted of peat at the heather-moorland (UK-Clo) and of mor humus at the dry Calluna heaths (DK-Mol, DK-Bra, NL-Old). Net $\mathrm{CH}_{4}$ uptake at the four temperate shrublands correlated negatively with the carbon stock in the upper $10 \mathrm{~cm}$ soil layer, suggesting a switch from net $\mathrm{CH}_{4}$ uptake to net $\mathrm{CH}_{4}$ emission as soils become enriched in organic matter. To our knowledge, such a relationship has only been reported in very few studies. For instance, Singh et al. (1997) showed that $\mathrm{CH}_{4}$ uptake in dry tropical forest soils correlated with both carbon and nitrogen content of the soils; two variables which increased in parallel. Within soil types, the content of organic matter and soil water often correlate, either because organic matter increases the water holding capacity (Hudson, 1994) or because high soil moisture hinders aerobic decomposition (Jungkunst and Fiedler, 2007). In line with this, the two sites with the highest carbon stock of the four temperate shrublands (i.e. UK-Clo and NL-Old) also had the highest soil moisture (Table 2). Consequently, the apparent carbon control on net $\mathrm{CH}_{4}$ exchange could be indirect via an effect on soil moisture, which limits $\mathrm{CH}_{4}$ diffusion towards the zone of methanotrophic activity (King, 1997; Dunfield, 2007). Singh et al. (1997), however, suggested a more direct control mechanism, where reduced net uptake of $\mathrm{CH}_{4}$ in carbon-rich soils was due to decreased $\mathrm{O}_{2}$ content in the soil atmosphere, resulting from higher decomposition rates. In our study, though, we found no relationship between carbon stock and soil respiratory $\mathrm{CO}_{2}$ emission at the four temperate shrubland sites. Potentially, organic matter stimulated methanogenesis by acting as a substrate for the process, leading to lower net $\mathrm{CH}_{4}$ uptake in the carbon-rich soils in our study. Most likely, the correlation between soil organic $\mathrm{C}$ and $\mathrm{CH}_{4}$ uptake was caused by a combination of these indirect and direct mechanisms, and we suggest that future studies aim at investigating this relationship in more details.

Previous studies of $\mathrm{N}$ additions to wetlands reported both positive and negative responses in net $\mathrm{CH}_{4}$ emissions, and the mechanisms involved are still under debate (Bodelier, 2011). In the present study, $\mathrm{NaNO}_{3}$ addition at the Scottish bog UK-Whi increased the $\mathrm{CH}_{4}$ efflux by almost $300 \%$, whereas $\mathrm{NH}_{4} \mathrm{Cl}$ or $\mathrm{NH}_{4} \mathrm{NO}_{3}$ additions had no overall effect. At the Scottish bog, the addition of $\mathrm{NaNO}_{3}$ raised $\mathrm{pH}$ in peat water from 3.7 to 4.0 (Table S1) and increased the availability of dissolved organic carbon (DOC), possibly because the slightly higher $\mathrm{pH}$ enhanced the solubility of organic compounds in the soil (Evans et al., 2008). In contrast, $\mathrm{NH}_{4} \mathrm{Cl}$ addition had no effect on $\mathrm{pH}$ or DOC. For comparison, $\mathrm{Mu}-$ rakami et al. (2005) raised the $\mathrm{pH}$ of four tropical acid peat soils by ca. $2 \mathrm{pH}$ units and observed a vast increase in the $\mathrm{CH}_{4}$ production potential. The authors suggested that this was due to increased substrate supply for methanogenic microorganisms derived from decomposed organic matter such as organic acids from peat humus. A similar mechanism could explain the enhanced $\mathrm{CH}_{4}$ efflux in response to $\mathrm{NaNO}_{3}$ addition at the Scottish bog UK-Whi.

At the Swedish peatland sites SE-Fäj and SE-Sto, addition of $\mathrm{NH}_{4} \mathrm{NO}_{3}$ had no significant effects on the $\mathrm{CH}_{4}$ flux. Although insignificant, the opposing effects of $\mathrm{N}$ addition on $\mathrm{CH}_{4}$ fluxes at SE-Fäj (increased efflux) and SE-Sto (decreased efflux), illustrates the importance of peatland type and site specific properties, such as plant composition and 

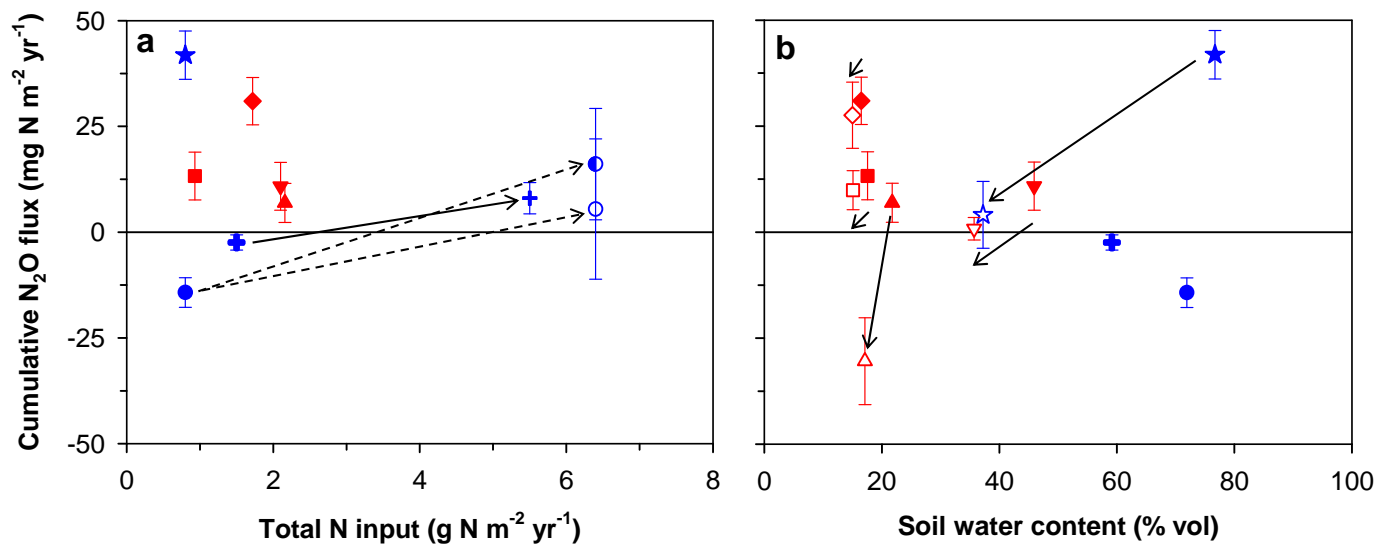

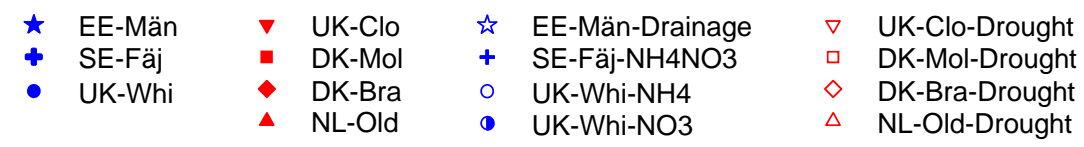

Fig. 6. Annual $\mathrm{N}_{2} \mathrm{O}$ flux at seven sites related to atmospheric $\mathrm{N}$ deposition (a) and mean annual soil water content, predominantly measured in the top $10 \mathrm{~cm}$ soil layer (b) (means $\pm \mathrm{SE}$ ). In addition to data for control plots, results are presented for plots that were exposed to either increased $\mathrm{N}$ input (a) or drainage and drought (b). Arrows indicate direction of treatment responses. Site codes are described in Table 1.
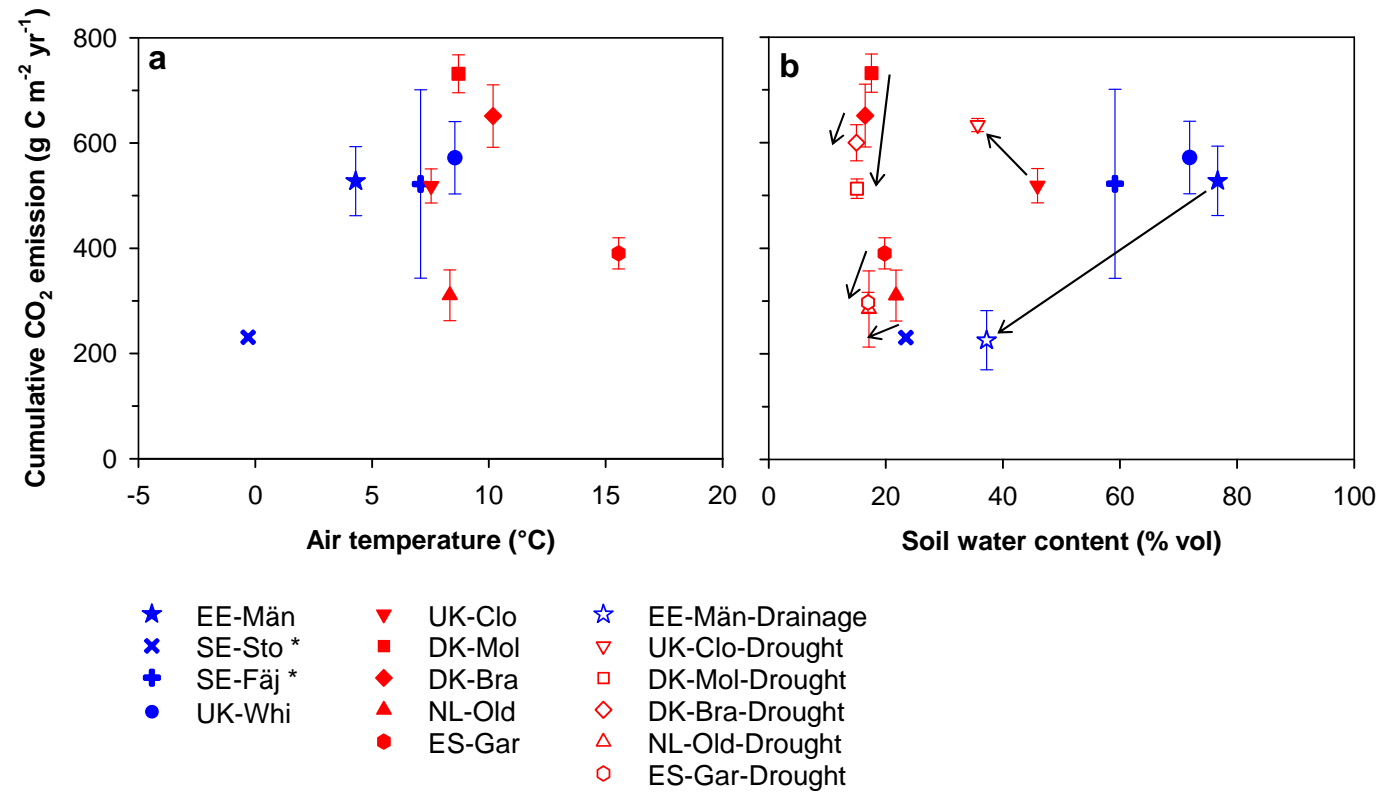

Fig. 7. Annual soil respiratory $\mathrm{CO}_{2}$ emission in control plots at the nine sites related to mean annual air temperature (a) and mean annual soil water content, predominantly measured in the top $10 \mathrm{~cm}$ soil layer (b) (means $\pm \mathrm{SE})$. In (b), data for drained or drought treated plots are also presented with arrows indicating direction of treatment responses. ${ }^{*}$ Data for SE-Sto and SE-Fäj is ecosystem respiratory $\mathrm{CO}_{2}$ emission. Site codes are described in Table 1.

productivity, $\mathrm{pH}$, substrate quality and general hydrology, for the effects of increased nutrient availability on peatland $\mathrm{CH}_{4}$ fluxes (Keller et al., 2006).

\section{2 $\quad \mathrm{N}_{2} \mathrm{O}$ fluxes}

Latest advances in knowledge suggest that three separate processes contribute to $\mathrm{N}_{2} \mathrm{O}$ emissions from soils. These are nitrification, denitrification and dissimilatory nitrate reduction to ammonium (DNRA), which are thought to be important sources of $\mathrm{N}_{2} \mathrm{O}$ in oxic, sub-oxic and anoxic microsites of the rhizosphere, respectively (Baggs, 2011). At individual field sites, daily $\mathrm{N}_{2} \mathrm{O}$ emission rates are typically reported to increase with soil moisture in the range from 50 to $90 \%$ water filled pore space (WFPS) (Smith et al., 2003). This 
relationship is probably caused by the associated decrease in $\mathrm{O}_{2}$ diffusion within the soil, leading to larger anaerobic microsites and thereby increased $\mathrm{N}_{2} \mathrm{O}$ production via denitrification (Smith et al., 2003) and possibly also DNRA. However, when soil moisture exceeds $90 \%$ WFPS, $\mathrm{N}_{2} \mathrm{O}$ emissions may decline as $\mathrm{N}_{2}$ is the final product of denitrification in most waterlogged soils (Davidson, 1991), although $\mathrm{pH}$ may also influences the $\mathrm{N}_{2} \mathrm{O} / \mathrm{N}_{2}$ loss ratio of denitrification (Šimek and Cooper, 2002).

In the present study, the lack of relationship between $\mathrm{N}_{2} \mathrm{O}$ emission and volumetric soil moisture across sites was possibly because $\mathrm{N}_{2} \mathrm{O}$ production is controlled by gas diffusivity, which is poorly reflected by volumetric soil moisture when comparing soils that differ in total porosity. At the site level, however, net $\mathrm{N}_{2} \mathrm{O}$ emissions declined consistently in response to reduced soil moisture caused by drought treatment, supporting previous results from drought experiments in a spruce forest (Goldberg and Gebauer, 2009). Furthermore, $\mathrm{N}_{2} \mathrm{O}$ emissions from the Estonia peatland EE-Män declined due to long-term drainage, which is in contrast to results from previous drainage experiments in ombrotrophic bogs (Martikainen et al., 1993; Regina et al., 1996). Apparently, increased tree growth at the drained area reduced the availability of soil nitrate (Table S1), which in combination with lower soil moisture caused the decline in $\mathrm{N}_{2} \mathrm{O}$ emissions.

Analysed across sites, the shrubland and peatland with highest $\mathrm{NO}_{3}^{-}$concentration in soil water also had the highest annual $\mathrm{N}_{2} \mathrm{O}$ emission within each ecosystem type, which illustrates that $\mathrm{N}_{2} \mathrm{O}$ production in these nutrient poor ecosystems was limited by $\mathrm{N}$ availability. This was supported by data at the site level, where $\mathrm{N}$ additions $\left(<60 \mathrm{~kg} \mathrm{Nha}^{-1} \mathrm{yr}^{-1}\right)$ that included nitrate led to increased $\mathrm{N}_{2} \mathrm{O}$ efflux from two peatlands, suggesting that denitrification or DNRA were involved in $\mathrm{N}_{2} \mathrm{O}$ production in these ecosystems, and that the processes were stimulated by increased substrate availability.

\subsection{Soil respiratory $\mathrm{CO}_{2}$ emission}

Annual soil respiratory $\mathrm{CO}_{2}$ emissions $\left(R_{\mathrm{S}}\right)$ ranged from 231 to $732 \mathrm{~g} \mathrm{C} \mathrm{m}^{-2} \mathrm{yr}^{-1}$ in control plots across the nine sites. The highest fluxes were observed at the temperate sites with annual temperatures ranging $8-10^{\circ} \mathrm{C}$, where ecosystem $\mathrm{C}$ turnover was less likely to be inhibited by either low temperatures (i.e. SE-Sto) or low summer soil moisture, resulting from low precipitation combined with high temperatures (i.e. ES-Gar). For comparison, Hibbard et al. (2005) reported $R_{\mathrm{s}}$ rates of $427-1805 \mathrm{~g} \mathrm{C} \mathrm{m}^{-2} \mathrm{yr}^{-1}$ across evergreen temperate forests, $509-867 \mathrm{~g} \mathrm{C} \mathrm{m}^{-2} \mathrm{yr}^{-1}$ in temperate/Mediterranean broadleaved forests and 181$488 \mathrm{~g} \mathrm{C} \mathrm{m}^{-2} \mathrm{yr}^{-1}$ in temperate/Mediterranean woodlands and savannas. The low fluxes at ES-Gar and NL-Old may be biased by the method applied, where headspace $\mathrm{CO}_{2}$ concentrations were determined by gas chromatography to- gether with $\mathrm{CH}_{4}$ and $\mathrm{N}_{2} \mathrm{O}$. This implied longer enclosure periods, i.e. 15 or $60 \mathrm{~min}$ compared to $1-5 \mathrm{~min}$ when measured directly in the field using an infrared gas analyzer. Longer enclosure periods may lead to non-linear development of headspace $\mathrm{CO}_{2}$ concentrations over time, and subsequently to underestimation of flux rates if calculations are based on linear regression (Heinemeyer and McNamara, 2011). However, EE-Män had the fourth highest $\mathrm{CO}_{2}$ flux among the nine sites and here fluxes were also determined using the gas chromatography method. Furthermore, Beier et al. (2009) estimated annual soil respiration at ES-Gar to be $440 \mathrm{~g} \mathrm{C} \mathrm{m}^{-2} \mathrm{yr}^{-1}$ based on other data with shorter enclosure periods $(4 \mathrm{~min})$, which still is lower than our estimates for six of the temperate sites. The low flux at the Dutch shrubland NL-Old could be due to the vegetation which, unlike the other sites, is a Calluna monoculture (Table 1). Van Vuuren and van der Eerden (1992) found that Calluna litter had a lower decomposition rate compared to litter of Deschampsia flexuosa and Molinia caerulea, which coincided with a double concentration of recalcitrant carbon compounds, indicated by the Klason lignin content. The low $\mathrm{CO}_{2}$ efflux at NL-Old could therefore result from a lower quality of the soil C pool compared to the other sites. Thus, our results indicate a pattern across the sites where soil respiration increased with temperature, but that the increase was offset in the warmest ecosystem due to low soil moisture, resulting from low precipitation combined with high temperatures. At the site level, however, warming treatment had no overall effect on soil respiratory $\mathrm{CO}_{2}$ losses, which may be due to the relatively mild temperature increase achieved with the passive warming technique of $0.5^{\circ} \mathrm{C}$ in the soil.

The prolonged drought or drainage manipulations showed stronger effects on soil respiration rates than both warming and $\mathrm{N}$ additions. Reduced soil moisture due to drought or drainage generally decreased soil respiration rates at the dry shrublands and the wet, long-term drained peatland EEMän, but increased soil respiration rates at the wet shrubland UK-Clo. As drainage most often leads to increased $\mathrm{CO}_{2}$ emissions in hydromorphic soils, at least in the short-term (Jungkunst and Fiedler, 2007; Danevčič et al., 2010; Maljanen et al., 2010), our results highlight how results may differ depending on the time since the experimental treatments were initiated. The drainage treatment at EE-Män started more than $30 \mathrm{yr}$ ago. Currently, the easy degradable fractions of the peat at EE-Män have already been decomposed and carbon cycling in the ecosystem has reached a new balance. In contrast, the drought treatment at UK-Clo has only been running for eight years, thus it is likely that the long-term effect may differ from the current short-term effect. Furthermore, the different response directions to prolonged drought between the sites show how important the initial conditions are for the strength and directions of the response to the treatment. 


\subsection{Experimental manipulations}

The quantitative effect on GHG fluxes of an experimental treatment is to a certain extent controlled by the magnitude of the treatment effects on environmental drivers. The question is whether our experimental manipulations have caused realistic changes in these drivers, which enable us to predict changes in GHG fluxes in future? On an annual basis, the prolonged drought treatment at the shrubland sites reduced moisture in the top soil by $10-20 \%$, which is a consistent decline when taking into account that the drought treatment was only carried out for about two months per year. In contrast, the warming treatment generally raised annual soil temperature at the sites by $0.5^{\circ} \mathrm{C}$. For comparison, annual mean soil temperatures in control plots at the Welsh shrubland UK-Clo varied between 7.0 and $8.7^{\circ} \mathrm{C}$ during the years 2000-2007 (data not shown). Thus, the overall warming effect of $0.5^{\circ} \mathrm{C}$ was less than the interannual variability at the site level. Furthermore, surface temperatures in Europe are projected to increase $2-5^{\circ} \mathrm{C}$ during this century, depending on which scenario is used (IPCC, 2007a). In conclusion, the lack of experimental warming effect on any of the three GHGs in our study could relate to an insufficient temperature increase obtained by the passive night-time warming treatment.

By contrast, drainage about $30 \mathrm{yr}$ ago of the Estonian peatland EE-Män has more than doubled the size of the oxic zone by lowering the water table from an annual depth of $15 \mathrm{~cm}$ to $38 \mathrm{~cm}$ below soil surface. As a result, the emission of all three GHGs had dropped dramatically after $30 \mathrm{yr}$ of treatment. Furthermore, annual $\mathrm{N}$ deposition was raised from $0.2,1.5$ and $0.8 \mathrm{~g} \mathrm{~N} \mathrm{~m}^{-2}$ to $4.2,5.5$ and $6.4 \mathrm{~g} \mathrm{~N} \mathrm{~m}^{-2}$ at the peatlands in northern (SE-Sto) and southern Sweden (SEFäj) as well as Scotland (UK-Whi), respectively. It is unlikely that total inorganic $\mathrm{N}$ deposition in these regions of Europe will reach such high levels in future (Galloway et al., 2004). However, global warming will lead to increased soil mineralization rates, releasing more inorganic $\mathrm{N}$ and other nutrients for plant uptake (Rustad et al., 2001; Mack et al., 2004). Also, large regions of South Asia are projected to receive more than $5 \mathrm{~g} \mathrm{~N} \mathrm{~m}^{-2} \mathrm{yr}^{-1}$ by 2050. Apart from the $\mathrm{CH}_{4}$ response to $\mathrm{NaNO}_{3}$ addition at the Scottish peatland UK-Whi, responses in GHGs fluxes to these relatively high $\mathrm{N}$ application rates were minor, illustrating resilience in the peatland ecosystems towards increased $\mathrm{N}$ deposition in the short term. However, in the longer term, changes in peatland plant composition and structure may occur, affecting the exchange of greenhouse gases. For instance, a warmer and drier climate with increased nutrient turnover will inflict competitive disadvantages for Sphagnum mosses, as they are adapted to cold, wet and nutrient-poor conditions (Clymo, 1984), and possibly stimulate growth of vascular plants.

\subsection{Responsiveness}

We observed some clear and interesting patterns in the responses of the three GHG fluxes across the nine investigated ecosystems. First of all, the observed responses to the manipulations of climate and atmospheric $\mathrm{N}$ deposition were stronger in relative terms for $\mathrm{CH}_{4}$ and $\mathrm{N}_{2} \mathrm{O}$ fluxes than for soil $\mathrm{CO}_{2}$ emissions. However, when comparing the fractional importance of each GHG to the total global warming response, then the observed changes in soil $\mathrm{CO}_{2}$ efflux dominated the response for the drainage, drought and warming treatments, where at least $91 \%$ of the global warming response was caused by changes in soil $\mathrm{CO}_{2}$ fluxes. The $\mathrm{N}$ addition treatments in peatlands that included $\mathrm{NO}_{3}^{-}$differed from this overall pattern by the dominance of a change in $\mathrm{CH}_{4}$ emissions (89\% of global warming response) compared to changes in the other gas species. This profound effect therefore also partly explains why responses in $\mathrm{CH}_{4}$ fluxes played a slightly more dominant role across the four peatlands (56\% of the global warming response) compared to soil $\mathrm{CO}_{2}$ emissions (44\% of global warming response) and $\mathrm{N}_{2} \mathrm{O}$ fluxes, which did not contribute significantly. In contrast, across the five shrublands including both drought and warming treatments, the response in soil $\mathrm{CO}_{2}$ emissions dominated ( $94 \%$ of global warming response) by far over responses in $\mathrm{CH}_{4}$ fluxes (2\% of global warming response) and $\mathrm{N}_{2} \mathrm{O}$ fluxes (4\% of global warming response).

Based on 109 different studies on effects of $\mathrm{N}$ addition on ecosystem GHG budgets, Liu and Greaver (2009) reported an overall increase in the terrestrial $\mathrm{CO}_{2}$ sink, but also that this was largely offset $(53-76 \%)$ by stimulated $\mathrm{CH}_{4}$ and $\mathrm{N}_{2} \mathrm{O}$ emissions. When adding up the absolute treatment responses for the three GHGs in our study, the $\mathrm{N}$ addition experiments led to a substantial positive climate forcing response. However, this was caused by a strong increase in $\mathrm{CH}_{4}$ emissions, whereas Liu and Greaver (2009) found that $\mathrm{N}_{2} \mathrm{O}$ was the primary contributor to global warming across the studies in their review. Warming effects were very small and not significant in the overall cross-site ANOVA. By contrast, the drought and drainage treatments led to a uniformly negative climate forcing response. Again, it must be emphasized that the response for the drained peatland in this study is the long-term response and it is likely that a substantial amount of carbon was lost from the ecosystem in the years immediately after drainage. But at least across the five shrubland ecosystems, the drought treatment showed a clear pattern of negative feedback to climate change.

In general, we recognize that the nine sites included in this study span differences in soil types, plant species, pretreatment conditions and present climate, and that the experimental treatments differed between sites. For this reason, generalized conclusions based on the mean responsiveness presented here should be drawn with caution. Especially, we lack information on responses in net primary production, and it is likely that the absolute responsiveness of net ecosystem 
$\mathrm{CO}_{2}$ fluxes would differ from that of soil $\mathrm{CO}_{2}$ emissions alone. Finally, none of the nine experiments included interactive effects with other climate drivers, which have previously been shown to be important for the combined response to multiple changes (Larsen et al., 2011).

\section{Conclusions}

With respect to environmental variables that seemed to influence the magnitude of GHG fluxes across the nine sites, temperature was identified as a main driver of $\mathrm{CH}_{4}$ emissions across the peatland sites. In contrast, net $\mathrm{CH}_{4}$ uptake at the temperate shrublands sites correlated negatively with the soil carbon stock, either due to a indirect effect via soil moisture or because soil carbon acted as a source for methanogenesis. Nitrate availability seemed to be a driver of $\mathrm{N}_{2} \mathrm{O}$ emissions at both peatland and shrubland sites, as the highest $\mathrm{N}_{2} \mathrm{O}$ efflux within each ecosystem type occurred at the site, which had the highest $\mathrm{NO}_{3}^{-}$concentrations in soil water. Soil respiratory $\mathrm{CO}_{2}$ emission showed maximum annual values at the temperate sites with mean annual temperature of $8-10^{\circ} \mathrm{C}$. Outside this range, in each end of our temperature gradient, soil respiration was either limited by low temperatures at the subarctic site SE-Sto or by low summer soil moisture at the Mediterranean site ES-Gar.

In terms of total climate forcing response, prolonged drought and long-term ( $>30 \mathrm{yr}$ ) drainage consistently reduced the soils' contribution to global warming. However, substantial amounts of $\mathrm{CO}_{2}$ were presumably lost from the drained peatland immediately after drainage. Furthermore, $\mathrm{N}$ addition to peatlands caused a considerable increase in the global warming contribution from these soils, primarily due to the response of $\mathrm{CH}_{4}$ emissions to $\mathrm{NaNO}_{3}$ addition at one site. Finally, experimental warming had no effect on any of the three GHGs, which could be explained by a modest temperature increase of $0.5^{\circ} \mathrm{C}$ imposed by the passive night-time warming treatment. When comparing the fractional importance of each GHG to the total numerical global warming response, then the change in $\mathrm{CO}_{2}$ efflux dominated the response in all treatments, except for $\mathrm{NO}_{3}^{-}$ addition where change in $\mathrm{CH}_{4}$ emissions accounted for the major part. Therefore, within the applied range of water, temperature and nutrient manipulations, soil $\mathrm{CO}_{2}$ emission plays a dominant role with respect to ecosystems' effect on global warming.

\section{Supplementary material related to this article is available online at: http://www.biogeosciences.net/9/ 3739/2012/bg-9-3739-2012-supplement.pdf.}

Acknowledgements. The authors gratefully acknowledge funding of the NitroEurope Integrated Project by the European Commission. In addition, work done at the Estonian site EE-Män was co-funded by the Estonian Ministry of Science and Education (grant SF1090065s07), and by the European Commission through European Social Fund (DoRa programme) and European Regional Fund (Centre of Excellence in Environmental Adaptation). Furthermore, measurements at the Swedish sites SE-Fäj and SE-Sto were carried out as part of NECC (Nordic Centre for Studies of Ecosystem Carbon Exchange and its Interactions with the Climate System), funded by the Joint Committee of the Nordic Natural Science Research Councils (NOS-N) and the Nordic Council of Ministers' pilot programme on climate change. Moreover, results from the Danish site DK-Bra was enabled by the CLIMAITE project, running this field site. Finally, work done at the Spanish site ES-Gar was co-funded by the Spanish Government (grant CGL2006-04025/BOS and CGL2010-17172/BOS), by the Catalan Government (grant SGR 2009-1511) and by Consolider-Ingenio Montes (grant CSD2008-00040). We wish to thank Michael Andersson, Kristian R. Albert, Antonio Vallejo and Joke Westerveld for taking part in the field work.

Edited by: J. W. Erisman

\section{References}

Ambus, P. and Robertson, G. P.: Automated near-continuous measurement of carbon dioxide and nitrous oxide fluxes from soil, Soil Sci. Soc. Am. J., 62, 394-400, 1998.

Andresen, L. C., Michelsen, A., Jonasson, S., Beier, C., and Ambus, P.: Glycine uptake in heath plants and soil microbes responds to elevated temperature, $\mathrm{CO}_{2}$ and drought, Acta Oecol., 35, 786796, 2009.

Baggs, E. M.: Soil microbial sources of nitrous oxide: recent advances in knowledge, emerging challenges and future direction, Current Opinion in Environmental Sustainability, 3, 321-327, 2011.

Beier, C., Emmett, B., Gundersen, P., Tietema, A., Peñuelas, J., Estiarte, M., Gordon, C., Gorissen, A., Llorens, L., Roda, F., and Williams, D.: Novel approaches to study climate change effects on terrestrial ecosystems in the field: Drought and passive nighttime warming, Ecosystems, 7, 583-597, 2004.

Beier, C., Emmett, B. A., Tietema, A., Schmidt, I. K., Peñuelas, J., Láng, E. K., Duce, P., De Angelis, P., Gorissen, A., Estiarte, M., de Dato, G. D., Sowerby, A., Kröel-Dulay, G., Lellei-Kovács, E., Kull, O., Mand, P., Petersen, H., Gjelstrup, P., and Spano, D.: Carbon and nitrogen balances for six shrublands across Europe, Global Biogeochem. Cy., 23, GB4008, doi:10.1029/2008GB003381, 2009.

Bodelier, P. L.: Interactions between nitrogenous fertilizers and methane cycling in wetland and upland soils, Current Opinion in Environmental Sustainability, 3, 379-388, 2011.

Bragazza, L., Freeman, C., Jones, T., Rydin, H., Limpens, J., Fenner, N., Ellis, T., Gerdol, R., Hajek, M., Hajek, T., Lacumin, P., Kutnar, L., Tahvanainen, T., and Toberman, H.: Atmospheric nitrogen deposition promotes carbon loss from peat bogs, P. Natl. Acad. Sci. USA, 103, 19386-19389, 2006.

Carter, M., Ambus, P., Albert, K. R., Larsen, K. S., Andersson, M., Prieme, A., van der Linden, L., and Beier, C.: Effects of elevated 
atmospheric $\mathrm{CO}_{2}$, prolonged summer drought and temperature increase on $\mathrm{N}_{2} \mathrm{O}$ and $\mathrm{CH}_{4}$ fluxes in a temperate heathland, Soil Biol. Biochem., 43, 1660-1670, 2011.

Castaldi, S. and Fierro, A.: Soil-atmosphere methane exchange in undisturbed and burned Mediterranean shrubland of southern Italy, Ecosystems, 8, 182-190, 2005.

Christensen, T. R., Michelsen, A., and Jonasson, S.: Exchange of $\mathrm{CH}_{4}$ and $\mathrm{N}_{2} \mathrm{O}$ in a subarctic heath soil: effects of inorganic $\mathrm{N}$ and $\mathrm{P}$ and amino acid addition, Soil Biol. Biochem., 31, 637641, 1999.

Christensen, T. R., Ekberg, A., Ström, L., Mastepanov, M., Panikov, N., Oquist, M., Svensson, B. H., Nykänen, H., Martikainen, P. J., and Oskarsson, H.: Factors controlling large scale variations in methane emissions from wetlands, Geophys. Res. Lett., 30, 1414, doi:10.1029/2002GL016848, 2003.

Clymo, R. S.: The limits to peat bog growth, Phil. Trans. R. Soc. B, 303, 605-654, 1984.

Clymo, R. S., Turunen, J., and Tolonen, K.: Carbon accumulation in peatland, Oikos, 81, 368-388, 1998.

Crill, P. M., Martikainen, P. J., Nykänen, H., and Silvola, J.: Temperature and $\mathrm{N}$ fertilization effects on methane oxidation in a drained peatland soil, Soil Biol. Biochem., 26, 1331-1339, 1994.

Curtis, C. J., Emmett, B. A., Reynolds, B., and Shilland, J.: How important is $\mathrm{N}_{2} \mathrm{O}$ production in removing atmospherically deposited nitrogen from UK moorland catchments?, Soil Biol. Biochem., 38, 2081-2091, 2006.

Danevčič, T., Mandic-Mulec, I., Stres, B., Stopar, D., and Hacin, J.: Emissions of $\mathrm{CO}_{2}, \mathrm{CH}_{4}$ and $\mathrm{N}_{2} \mathrm{O}$ from Southern European peatlands, Soil Biol. Biochem., 42, 1437-1446, 2010.

Davidson, E. A.: Fluxes of nitrous oxide and nitric oxide from terrestrial ecosystems, in: Microbial production and consumption of greenhouse gases: Methan, nitrogen oxides, and halomethanes, edited by: Rogers, J. E. and Whitman, W. B., Am. Soc. Microbiol., Washington DC, USA, 219-235, 1991.

Dinsmore, K. J., Skiba, U. M., Billett, M. F., Rees, R. M., and Drewer, J.: Spatial and temporal variability in $\mathrm{CH}_{4}$ and $\mathrm{N}_{2} \mathrm{O}$ fluxes from a Scottish ombrotrophic peatland: Implications for modelling and up-scaling, Soil Biol. Biochem., 41, 1315-1323, 2009.

Drewer, J., Lohila, A., Aurela, M., Laurila, T., Minkkinen, K., Penttila, T., Dinsmore, K. J., Mckenzie, R. M., Helfter, C., Flechard, C., Sutton, M. A., and Skiba, U. M.: Comparison of greenhouse gas fluxes and nitrogen budgets from an ombotrophic bog in Scotland and a minerotrophic sedge fen in Finland, Eur. J. Soil Sci., 61, 640-650, 2010.

Dunfield, P.: The soil methane sink, in: Greenhouse gas sinks, edited by: Reay, D., Hewitt, C., Smith, K., and Grace, J., CAB International, Oxfordshire, UK, 152-170, 2007.

Dunfield, P., Knowles, R., Dumont, R., and Moore, T. R.: Methane production and consumption in temperate and subarctic peat soils - response to temperature and $\mathrm{pH}$, Soil Biol. Biochem., 25, 321$326,1993$.

Dutaur, L. and Verchot, L. V.: A global inventory of the soil $\mathrm{CH}_{4}$ sink, Global Biogeochem. Cy., 21, GB4013, doi:10.1029/2006GB002734, 2007.

EEA: The magnitude of semi-natural vegetation, open bare surfaces, wetland and water bodies, European Environmental Agency, http://www.eea.europa.eu (last access: December 2011), 2006.
Emmett, B. A., Beier, C., Estiarte, M., Tietema, A., Kristensen, H. L., Williams, D., Peñuelas, J., Schmidt, I., and Sowerby, A.: The response of soil processes to climate change: Results from manipulation studies of shrublands across an environmental gradient, Ecosystems, 7, 625-637, 2004.

Evans, C., Goodale, C., Caporn, S., Dise, N., Emmett, B., Fernandez, I., Field, C., Findlay, S., Lovett, G., Meesenburg, H., Moldan, F., and Sheppard, L.: Does elevated nitrogen deposition or ecosystem recovery from acidification drive increased dissolved organic carbon loss from upland soil? A review of evidence from field nitrogen addition experiments, Biogeochemistry, 91, 13-35, 2008.

Firestone, M. K. and Davidson, E. A.: Microbiological basis of NO and $\mathrm{N}_{2} \mathrm{O}$ production and consumption in soil, in: Exchange of trace gases between terrestrial ecosystems and the atmosphere, edited by: Andreae, M. O. and Schimel, D. S., John Wiley \& Sons, Chichester, UK, 7-21, 1989.

Galloway, J. N., Dentener, F. J., Capone, D. G., Boyer, E. W., Howarth, R. W., Seitzinger, S. P., Asner, G. P., Cleveland, C. C., Green, P. A., Holland, E. A., Karl, D. M., Michaels, A. F., Porter, J. H., Townsend, A. R., and Vorosmarty, C. J.: Nitrogen cycles: past, present, and future, Biogeochemistry, 70, 153-226, 2004.

Goldberg, S. D. and Gebauer, G.: $\mathrm{N}_{2} \mathrm{O}$ and NO fluxes between a Norway spruce forest soil and atmosphere as affected by prolonged summer drought, Soil Biol. Biochem., 41, 1986-1995, 2009.

Gorham, E.: Northern peatlands - role in the carbon cycle and probable responses to climatic warming, Ecol. Appl., 1, 182-195, 1991.

Heinemeyer, A. and McNamara, N. P.: Comparing the closed static versus the closed dynamic chamber flux methodology: Implications for soil respiration studies, Plant Soil, 346, 145-151, 2011.

Hibbard, K. A., Law, B. E., Reichstein, M., and Sulzman, J.: An analysis of soil respiration across northern hemisphere temperate ecosystems, Biogeochemistry, 73, 29-70, 2005.

Hudson, B. D.: Soil organic-matter and available water capacity, J. Soil Water Conserv., 49, 189-194, 1994.

IPCC: Climate change 2007: Synthesis report, Contribution of working groups I, II and III to the fourth assessment report of the Intergovernmental Panel on Climate Change, edited by: Pachauri, R. and Reisinger, A., IPCC, Geneva, Switzerland, 104 pp., 2007a.

IPCC: Climate change 2007: The physical science basis. Contribution of working group I to the fourth assesment report of the Intergovernmental Panel on Climate Change, edited by: Solomon, S., Qin, D., Manning, M., Chen, Z., Marquis, M., Averyt, K., Tignor, M., and Miller, H., Cambridge University Press, Cambridge, UK and New York, NY, USA, 996 pp., 2007b.

Joabsson, A., Christensen, T. R., and Wallen, B.: Vascular plant controls on methane emissions from northern peatforming wetlands, Trends Ecol. Evol., 14, 385-388, 1999.

Jungkunst, H. F. and Fiedler, S.: Latitudinal differentiated water table control of carbon dioxide, methane and nitrous oxide fluxes from hydromorphic soils: feedbacks to climate change, Global Change Biol., 13, 2668-2683, 2007.

Keller, J. K., Bauers, A. K., Bridgham, S. D., Kellogg, L. E., and Iversen, C. M.: Nutrient control of microbial carbon cycling along an ombrotrophic-minerotrophic peatland gradient, J. Geophys. Res.-Biogeo., 111, G03006, doi:10.1029/2005JG000152, 
2006.

Kim, J. and Verma, S. B.: Soil surface $\mathrm{CO}_{2}$ flux in a Minnesota peatland, Biogeochemistry, 18, 37-51, 1992.

Kimmel, K. and Mander, Ü.: Ecosystem services of peatlands: Implications for restoration, Prog. Phys. Geog., 34, 491-514, 2010.

King, G. M.: Responses of atmospheric methane consumption by soils to global climate change, Global Change Biol., 3, 351-362, 1997.

Lai, D. Y. F.: Methane dynamics in northern peatlands: A review, Pedosphere, 19, 409-421, 2009.

Larsen, K. S., Grogan, P., Jonasson, S., and Michelsen, A.: Respiration and microbial dynamics in two subarctic ecosystems during winter and spring thaw: Effects of increased snow depth, Arct. Antarct. Alp. Res., 39, 268-276, 2007.

Larsen, K. S., Andresen, L., Beier, C., Jonasson, S., Albert, K., Ambus, P., Arndal, M. F., Carter, M., Christensen, S., Holmstrup, M., Ibrom, A., Kongstad, J., van der Linden, L., Maraldo, K., Michelsen, A., Mikkelsen, T. N., Pilegaard, K., Prieme, A., RoPoulsen, H., Schmidt, IK., Selsted, M., and Stevnbak, K. Reduced $\mathrm{N}$ cycling in response to elevated $\mathrm{CO}_{2}$, warming, and drought in a Danish heathland: Synthesizing results of the CLIMAITE project after two years of treatments, Global Change Biol., 17, 1884-1899, 2011.

Lindroth, A., Lund, M., Nilsson, M., Aurela, M., Christensen, T. R., Laurila, T., Rinne, J., Riutta, T., Sagerfors, J., Ström, L., Tuovinen, J. P., and Vesala, T.: Environmental controls on the $\mathrm{CO}_{2}$ exchange in north European mires, Tellus B, 59, 812-825, 2007.

Littell, R., Stroup, W., and Freund, R.: SAS for linear models, SAS Institute Inc., Cary, NC, USA, 2002.

Liu, L. L. and Greaver, T. L.: A review of nitrogen enrichment effects on three biogenic GHGs: the $\mathrm{CO}_{2}$ sink may be largely offset by stimulated $\mathrm{N}_{2} \mathrm{O}$ and $\mathrm{CH}_{4}$ emission, Ecol. Lett., 12, 11031117, 2009.

Lund, M., Christensen, T. R., Mastepanov, M., Lindroth, A., and Ström, L.: Effects of $\mathrm{N}$ and $\mathrm{P}$ fertilization on the greenhouse gas exchange in two northern peatlands with contrasting $\mathrm{N}$ deposition rates, Biogeosciences, 6, 2135-2144, doi:10.5194/bg-62135-2009, 2009.

Mack, M. C., Schuur, E. A. G., Bret-Harte, M. S., Shaver, G. R., and Chapin, F. S.: Ecosystem carbon storage in arctic tundra reduced by long-term nutrient fertilization, Nature, 431, 440-443, 2004.

Maljanen, M., Sigurdsson, B. D., Guðmundsson, J., Óskarsson, H., Huttunen, J. T., and Martikainen, P. J.: Greenhouse gas balances of managed peatlands in the Nordic countries - present knowledge and gaps, Biogeosciences, 7, 2711-2738, doi:10.5194/bg7-2711-2010, 2010.

Martikainen, P. J., Nykänen, H., Crill, P., and Silvola, J.: Effect of a lowered water table on nitrous oxide fluxes from northern peatlands, Nature, 366, 51-53, 1993.

Mikkelsen, T. N., Beier, C., Jonasson, S., Holmstrup, M., Schmidt, I. K., Ambus, P., Pilegaard, K., Michelsen, A., Albert, K., Andresen, L. C., Arndal, M. F., Bruun, N., Christensen, S., Danbaek, S., Gundersen, P., Jorgensen, P., Linden, L. G., Kongstad, J., Maraldo, K., Prieme, A., Riis-Nielsen, T., Ro-Poulsen, H., Stevnbak, K., Selsted, M. B., Sorensen, P., Larsen, K. S., Carter, M. S., Ibrom, A., Martinussen, T., Miglietta, F., and Sverdrup, H.: Experimental design of multifactor climate change experiments with elevated $\mathrm{CO}_{2}$, warming and drought: the CLIMAITE project, Funct. Ecol., 22, 185-195, 2008.
Minkkinen, K. and Laine, J.: Vegetation heterogeneity and ditches create spatial variability in methane fluxes from peatlands drained for forestry, Plant Soil, 285, 289-304, 2006.

Montanarella, L., Jones, R. J. A., and Hiederer, R.: The distribution of peatland in Europe, Mires and Peat, 1, 1-10, 2006.

Murakami, M., Furukawa, Y., and Inubushi, K.: Methane production after liming to tropical acid peat soil, Soil Sci. Plant Nutr., 51, 697-699, 2005.

Niinemets, Ü., Ellsworth, D. S., Lukjanova, A., and Tobias, M.: Site fertility and the morphological and photosynthetic acclimation of Pinus sylvestris needles to light, Tree Physiol., 21, 1231-1244, 2001.

Nykänen, H., Vasander, H., Huttunen, J. T., and Martikainen, P. J.: Effect of experimental nitrogen load on methane and nitrous oxide fluxes on ombrotrophic boreal peatland, Plant Soil, 242, 147155, 2002.

Peñuelas, J., Gordon, C., Llorens, L., Nielsen, T., Tietema, A., Beier, C., Bruna, P., Emmett, B., Estiarte, M., and Gorissen, A.: Nonintrusive field experiments show different plant responses to warming and drought among sites, seasons, and species in a north-south European gradient, Ecosystems, 7, 598-612, 2004.

Peñuelas, J., Sardans, J., Rivas-ubach, A., and Janssens, I. A.: The human-induced imbalance between C, N and P in Earth's life system, Global Change Biol., 18, 3-6, 2012.

Portsmuth, A., Niinemets, Ü., Truus, L., and Pensa, M.: Biomass allocation and growth rates in Pinus sylvestris are interactively modified by nitrogen and phosphorus availabilities and by tree size and age, Can. J. Forest Res., 35, 2346-2359, 2005.

Price, S., Whitehead, D., Sherlock, R., McSeveny, T., and Rogers, G.: Net exchange of greenhouse gases from soils in an unimproved pasture and regenerating indigenous Kunzea ericoides shrubland in New Zealand, Aust. J. Soil Res., 48, 385-394, 2010.

Regina, K., Nykanen, H., Silvola, J., and Martikainen, P. J.: Fluxes of nitrous oxide from boreal peatlands as affected by peatland type, water table level and nitrification capacity, Biogeochemistry, 35, 401-418, 1996.

Roslev, P., Iversen, N., and Henriksen, K.: Oxidation and assimilation of atmospheric methane by soil methane oxidizers, Appl. Environ. Microb., 63, 874-880, 1997.

Roulet, N. T. and Moore, T. R.: The effect of forestry drainage practices on the emission of methane from northern peatlands, Can. J. Forest Res., 25, 491-499, 1995.

Rustad, L. E., Campbell, J. L., Marion, G. M., Norby, R. J., Mitchell, M. J., Hartley, A. E., Cornelissen, J. H. C., and Gurevitch, J.: A meta-analysis of the response of soil respiration, net nitrogen mineralization, and aboveground plant growth to experimental ecosystem warming, Oecologia, 126, 543-562, 2001.

Saarnio, S. and Silvola, J.: Effects of increased $\mathrm{CO}_{2}$ and $\mathrm{N}$ on $\mathrm{CH}_{4}$ efflux from a boreal mire: a growth chamber experiment, Oecologia, 119, 349-356, 1999.

SAS Institute: SAS/STAT User's Guide, release 9.1. Statistical Analysis System Institute, Cary, NC, USA, 2003.

Schlesinger, W. H. and Andrews, J. A.: Soil respiration and the global carbon cycle, Biogeochemistry, 48, 7-20, 2000.

Schmidt, I. K., Tietema, A., Williams, D., Gundersen, P., Beier, C., Emmett, B. A., and Estiarte, M.: Soil solution chemistry and element fluxes in three European heathlands and their responses to warming and drought, Ecosystems, 7, 638-649, 2004. 
Selsted, M. B., van der Linden, L., Ibrom, A., Michelsen, A., Larsen, K. S., Pedersen, J. K., Mikkelsen, T. N., Pilegaard, K., Beier, C., and Ambus, P.: Soil respiration is stimulated by elevated $\mathrm{CO}_{2}$ and reduced by summer drought: three years of measurements in a multifactor ecosystem manipulation experiment in a temperate heathland (CLIMAITE), Global Change Biol., 18, 1216-1230, 2012.

Sheppard, L. J., Crossley, A., Leith, I. D., Hargreaves, K. J., Carfrae, J. A, Dijk, N. van, Cape, J. N., Sleep, D, Fowler, D., and Raven, J. A.: An automated wet deposition system to compare the effects of reduced and oxidised $\mathrm{N}$ on ombrotrophic bog species: Practical considerations, Water, Air, Soil Pollut., 4, 197-205, 2011.

Šimek, M. and Cooper, J. E.: The influence of soil pH on denitrification: progress towards the understanding of this interaction over the last 50 years, Eur. J. Soil Sci., 53, 345-354, 2002.

Singh, J. S., Singh, S., Raghubanshi, A. S., Singh, S., Kashyap, A. K., and Reddy, V. S.: Effect of soil nitrogen, carbon and moisture on methane uptake by dry tropical forest soils, Plant Soil, 196, 115-121, 1997.

Smith, K. A.: The potential for feedback effects induced by global warming on emissions of nitrous oxide by soils, Global Change Biol., 3, 327-338, 1997.

Smith, K. A., Ball, T., Conen, F., Dobbie, K. E., Massheder, J., and Rey, A.: Exchange of greenhouse gases between soil and atmosphere: interactions of soil physical factors and biological processes, Eur. J. Soil Sci., 54, 779-791, 2003.
Sowerby, A., Emmett, B. A., Tietema, A., and Beier, C.: Contrasting effects of repeated summer drought on soil carbon efflux in hydric and mesic heathland soils, Global Change Biol., 14, 2388 2404, 2008.

Ström, L., Ekberg, A., Mastepanov, M., and Christensen, T. R.: The effect of vascular plants on carbon turnover and methane emissions from a tundra wetland, Global Change Biol., 9, 1185-1192, 2003.

van Vuuren, M. M. I. and van der Eerden, L. J.: Effects of three rates of atmospheric nitrogen deposition enriched with ${ }^{15} \mathrm{~N}$ on litter decomposition in a heathland, Soil Biol. Biochem., 24, 527-532, 1992.

Veber, K.: Vegetation history of the Endla mire system, in: Estonian wetlands and their life, edited by: Kumari, E., Valgus, Tallinn, Estonia, 160-182, 1974.

von Arnold, K., Weslien, P., Nilsson, M., Svensson, B. H., and Klemedtsson, L.: Fluxes of $\mathrm{CO}_{2}, \mathrm{CH}_{4}$ and $\mathrm{N}_{2} \mathrm{O}$ from drained coniferous forests on organic soils, Forest Ecol. Manag., 210, 239-254, 2005.

Wessel, W. W., Tietema, A., Beier, C., Emmett, B. A., Penuelas, J., and Riis-Nielsen, T.: A qualitative ecosystem assessment for different shrublands in western Europe under impact of climate change, Ecosystems, 7, 662-671, 2004. 